Ankara Üniversitesi

SBF Dergisi,

Cilt 70, No. 1, 2015, s. 163 - 193

\title{
TEORIDEN PRATIĞE: SURIYE KRIZi VE ULUSLARARASI TOPLUM
}

\author{
Arş. Gör. Ali Onur Tepeciklioğlu \\ Ege Üniversitesi \\ İktisadi ve İdari Bilimler Fakültesi
}

\author{
Arş. Gör. Dr. Elem Eyrice Tepeciklioğlu \\ Yaşar Üniversitesi \\ İktisadi ve İdari Bilimler Fakültesi
}

\section{Öz}

$\mathrm{Bu}$ çalışma uluslararası toplumun varlığını ve işlerliğini Suriye krizi üzerinden tartışmayı amaçlamaktadır. Çalışmada uluslararası toplum, ulus devletlerin oluşturduğu bir cemiyet olarak tanımlanacak ve bu cemiyetin işlerliği ve varlığı, kurumları vasıtasıyla ortaya konacaktır. Uluslararası toplum kavramı, hem gündelik yaşamda hem de Uluslararası İlişkiler çalışmalarında sıklıkla kullanılmaktadır ancak, özellikle Türkçe literatürde kavramın karşılık geldiği pratik yeterince net bir biçimde tanımlanmamış bulunmaktadır. Bu nedenle çalışmada İngiliz ekolünün uluslararası toplum kavramı benimsenerek, diplomasi, savaş, büyük güçler yönetimi, güçler dengesi ve uluslararası hukuk kurumlarının bu topluma nasıl işlerlik kazandırdığı incelenecektir. Çalışmanın temel katkısı, İngiliz ekolünün Türkçe Uluslararası İlişkiler literatüründe bilinirliğinin arttırılması ve Uluslararası İlişkiler çalışmalarında teori-pratik boyutunun güçlendirilmesi olacaktır. Bu amaç doğrultusunda, öncelikle uluslararası toplumun kavramsal olarak ne ifade ettiği tartışılarak kurumları tanımlanacak, sonrasında Suriye krizinde bu kurumların nasıl işlediği açıklanarak uluslararası toplumun sadece bir kavram değil aynı zamanda bir gerçeklik olduğu vurgulanacaktır. dengesi

Anahtar Sözcükler: Suriye krizi, uluslararası toplum, büyük güçler yönetimi, diplomasi, güçler

\section{From Theory to Practice: Syrian Crisis and International Society}

\section{Abstract}

This study analyzes the existence and functionality of international society over the Syrian crisis. In this context, international society will be defined as a community comprised of nation-states while the functionality and the existence of this community will be put forward through its institutions. The term international society is frequently used both in daily life and in International Relations (IR) studies. However, the corresponding practice in the Turkish literature has not been clearly defined. This explains why this study embraces the international society concept of the English School and how its institutions - namely diplomacy, war, great power management, balance of power, and international law - bring this international society into force. The major contribution of the study will be to raise awareness concerning the English School of thought in Turkish International Relations literature, as well as to strengthen the theory-practice dimension of IR studies. Within this context, the article will first discuss the conceptualization of international society and then proceed to define its institutions, followed by an analysis of how these institutions functioned during the Syrian crisis. The major argument of this paper is that international society is not merely a concept but a reality itself.

Keywords: Syrian crisis, international society, great power management, diplomacy, balance of power

*Makale geliş tarihi: 05.08 .2014

Makale kabul tarihi: 27.11.2014 
- Ankara Üniversitesi SBF Dergisi • 70(1)

\section{Teoriden Pratiğe: Suriye Krizi ve Uluslararası Toplum}

\section{Giriş}

$\mathrm{Bu}$ çalışmanın amacı, uluslararası toplumun sadece gündelik yaşamda kullanılan bir kavram olmadığını, aynı zamanda bir gerçeklik olduğunu ortaya koymaktır. Uluslararası toplum günümüz uluslararası ilişkilerinin temel karakteristiğidir ve varlığı, kurumlarının belirli norm ve kurallar çerçevesinde işleyişi ile kanıtlanabilir. Bu çalışmada, kuramsal olarak tanımlanmış bulunan bu norm, kural ve kurumların nasıl çalıştığı Suriye krizi pratiğinde gösterilecektir. Söz konusu krizde bu norm ve kurallar çerçevesinde uluslararası toplum işlerliğini sürdürmüş ve düzenin korunması amacı ile büyük güçler yönetimi, diplomasi, uluslararası hukuk, güçler dengesi gibi kurumlar çalıştırılmıştır. Dolayısıyla, yönetsel anlamda iki yüzden fazla parçaya bölünmüş olan günümüz dünyası sadece çatışma ve şiddetin var olduğu bir "arena" değil aynı zamanda işbirliği ve dayanışmanın da bulunduğu, kurumları vasıtasıyla belirli amaçlara yönelik hareket eden kendine has bir toplumdur. $\mathrm{Bu}$ nedenle bu çalışmanın konusunu oluşturan Suriye krizi gibi uluslararası krizler, uluslararası toplumun amaçları doğrultusunda idare edilebilir. Başka bir deyişle, devletler, gündelik çıkarları çatışsa dahi farklı bir düzen içerisinde hareket edebilirler.

Uluslararası toplum kavramı hem gündelik hayatta hem de Uluslararası İlişkiler literatüründe gittikçe artan bir oranda kullanılmaktadır. Kavrama olan ilginin özellikle Uluslararası İlişkiler disiplini içerisinde yaygınlaşması, bu kavramı ortaya atan İngiliz ekolüne olan alakanın artması ile paralellik göstermektedir. Uluslararası İlişkilerde İngiliz ekolü, normatif bir bakış açısı ile uluslararası ilişkilerin salt kaos ve çatışmadan ibaret olmadığı, aynı zamanda insanlar/devletler arasında paylaşlan değerlerin/ortak çıkarların uluslararası siyasetin farklı boyutlarını oluşturduğunu savunan çoğunlukla İngiltere'de eğitim görmüş bir grup düşünür ve onların yaklaşımlarını takip eden çağdaşlarına verilen addır. Bu ekol 1960'l yıllarda ortaya çıkmış olsa da Soğuk Savaşın bitimi ile birlikte kan kaybına uğrayan realist ekolün dikkate 
değer bir alternatifini oluşturmaktadır. Özetle, kavramın literatürde bu denli yaygın bir biçimde kullanılması Uluslararası İlişkilerdeki yeni arayışların da bir neticesidir.

Her ne kadar uluslararası toplum dediğimiz şey üyelerinin insanlar olduğu yerel toplumlar gibi rahatça gözlemlenebilecek bir gerçeklik olmasa da, bu onun gerçek dünyada var olmadığı, sadece bir söz ya da kavram olduğu anlamına gelmez. Uluslararası toplumun varlığının gözle görülmesinin zorluğu yerel toplumlardaki gibi tek bir merkezden idare edilmemesinden kaynaklanmaktadır. Bilindiği üzere yerel toplumlarda yönetim ve yaptırım gücünü bir siyasi yapı (günümüzde devlet ya da ulus-devlet) tekelinde tutarken, uluslararası toplumda böyle bir üst otorite söz konusu değildir, yani, en basit ifadesiyle uluslararası ilişkiler anarşiktir. Ancak İngiliz ekolü, yerel toplumlarda olduğu gibi, uluslararası toplumda da ortak kural ve çıkarlar çerçevesinde üretilmiş kurum, norm ve kurallar vasıtası ile bir düzenin bulunduğunu iddia etmektedir. Dolayısıyla uluslararası toplum vardır.

Suriye krizinin çalışmada örnek olay olarak incelenmesinin nedeni, uluslararas1 toplumun bir anlamda varlığının en önemli göstergesi olan kurumların çalışmasının en net gözlemlenebileceği olaylardan birisi olmasıdır. Ancak uluslararası toplumun sadece kriz anlarında işlerlik kazanmadığının, bir gerçeklik olduğunun ve uluslararası arenadaki tüm eylemlerin bir toplumsallık içerisinde vuku bulduğunun da atlanmaması gerekmektedir. Suriye'deki krizin halen sürmesi ve sonucunun kestirilememesi çalışma açısından bir sorun yaratmamaktadır. Zira çalışmanın ilerleyen bölümlerinde de ayrıntılı olarak açıklanacağı üzere, uluslararası toplum kavramı kapsayıcıdır ve çeşitli olasılıkları içerir. Bu yüzden Suriye krizinin bir insani müdahaleyle ya da müdahale olmaksızın, hükümet güçlerinin ya da muhaliflerin üstünlüğüyle, hatta Suriye'nin birkaç parçaya bölünerek yeni politik yapıların ortaya çıkmasıyla sonuçlanması çalışmanın sonuçlarını ya da argümanlarını etkilemeyecektir.

$\mathrm{Bu}$ ve daha burada sayılmayan birçok olası sonuç uluslararası toplum kavramının ya da teorisinin kapsamı dâhilindedir. $\mathrm{Bu}$ nedenle uluslararası toplum teorisi kısıtlı ya da belirli durumlara uygulanabilecek bir yaklaşım değil, uluslararası ilişkileri genel manada anlamaya/açıklamaya çalışan bir teoridir. Çalışma, yukarıda sayılan amaçlar çerçevesinde öncelikle uluslararası toplumun ne olduğunu ve günümüz uluslararası toplumunun temel değerleri, kuralları ve kurumlarının yapısı ile temel işleyişlerini teorik bir perspektif aracılığıyla sunacak daha sonra Suriye krizinde bu kurumların her birinin var olan kural ve normlar çerçevesinde nasıl işlediğini ortaya koyacaktır. 


\section{Uluslararası Toplum ve Kurumları}

Uluslararası İlişkiler disiplini, devletler arasındaki ilişkilerden fazlasını incelediği için kapsayıcı olarak nitelendirilebilirse de, günümüzde ulusdevletler çağında yaşadığımız yaygın kabul gören bir gerçekliktir. Ulusdevletin gücünün günbegün erozyona uğradığı argümanı disiplinde yaygın bir biçimde kabul görmeye başlamış da olsa; ulus-devlet hala uluslararası ilişkilerde başat aktör konumunu sürdürmektedir. Dolayısıyla, günümüzde uluslararası ilişkilerin gerçekliğini ulus-devletler arasındaki ilişkiler oluşturmaktadır. Tarih boyunca, farklı insan toplulukları değişik biçimlerde örgütlenerek bir arada yaşamışlardır. Uluslararası ilişkiler disiplini ise bu farklı örgütlenmelerin birbirleri ile ilişkilerini anlamak/açıklamak üzere çeşitli kavram ve kuramlar üretmiştir. Bu makalenin konusunu oluşturan uluslararas1 toplum, işte bu kavram/kuramlardan ulus-devletler arasındaki ilişkileri anlama/açıklama çabası ile oluşturulmuştur. Fakat uluslararası toplumun ulus devletler arasındaki ilişkileri incelemek üzere üretilmiş yegâne kavram olmadığını da vurgulamak gerekmektedir. Sözün özü, tüm kavramsallaştırmalar gibi küresel uluslararası toplum da -zira günümüz uluslararası toplumu tüm küreye nüfuz etmiştir- zaman ve mekâna bağımlıdır ve aşağı yukarı son üç yüz yıllık bir sürede uluslararası arenaya hâkim olan siyasi yapı türünün birbirleri ile toplumsallık arz edecek biçimde ilişki kurduklarını nitelemektedir.

Uluslararası toplum, adından da anlaşılacağı üzere üyeleri ulus-devletler olan bir topluma işaret etmektedir. Ancak ulus-devletlerin birbirleri ile ilişki kurdukları her yapı bir uluslararası toplum değildir. Ulus-devletlerin birbirleri ile ilişkilerinin toplumsallık arz etmediği noktada, disiplinde uluslararası toplum kavramına nazaran çok daha yaygın olarak kullanılan "uluslararası sistem" kavramı gündeme gelmektedir. Uluslararası sistem, basit bir şekilde, birinin eyleminin ve/veya hareketinin diğerini/diğerlerini etkileyeceği bir karş11klı ilişki içerisinde bulunan aktörlerin oluşturduğu yap1 olarak tanımlanabilir (Bull, 1985: 14). Uluslararası ilişkilerde sistem düşüncesinin en önemli temsilcilerinden olan Kenneth Waltz, uluslararası ilişkilerin bütüncül bir perspektiften incelenmesi gerektiği fikrini ortaya atmıştır. Başka bir deyişle, sadece sistemi oluşturan parçaların davranışlarını incelemektense, sisteme bütüncül bir biçimde bakmak gereklidir, çünkü sistem onu oluşturan parçaların davranışını belirleyen yapıdır (Waltz, 1959: 238). Realistlere göre uluslararası sistem bir üst otoritenin bulunmamasından ötürü anarşiktir ve düzen ancak güç ile sağlanır (Walt, 1998: 31-32; Mearsheimer, 1994: 10). Özellikle neo-realist ekolün belirttiği üzere sistem içerisindeki tüm devletler fonksiyonları bakımından eşitlerdir ancak, bu fonksiyonları yerine getirebilme kapasiteleri onları birbirlerinden ayırır. Dolayısıyla, devletler bekalarını sağlamak amacı ile 
güç peşinde koşarlar ve çıkarlarının birbirleri ile çeliştiği noktada bu gücü kullanmaktan çekinmezler (Waltz, 1979: 79-82).

Uluslararas1 sistem kavramının uluslararas1 toplum kavramından ayrıldığı en önemli nokta, birincisinin iradi bir birlikteliği değil zorunlu ve istenç dışı bir birlikteliği nitelemesidir. Hedley Bull (1985: 14), uluslararası sistemi "iki ya da daha fazla devletin, ortak çıkar ve değerlerin bilincinde olmadan, birbirleri ile ilişkilerinde ortak bir kurallar dizisine bağlı olmaksızın ve ortak kurumların çalışmasını paylaşmadan, bir diğerinin hareketlerini hesaplamasında önemli bir faktör olduğunun farkında olarak, etkileşim içerisinde bulunması" olarak tanımlamaktadır. Bu nedenle uluslararası sistem iradi değildir. Devletler ortak çıkar ve kuralları paylaşmazlar. Bu bir nevi her aktörün diğerlerinin davranışlarını göz önünde bulundurarak hareket ettiği zorunlu bir birlikteliktir ve daimi kural ile kurumların varlığından söz edilemez.

Uluslararas1 toplum ise, uluslararas1 sistemin aksine, iradi olarak bir araya gelmiş devletlerin birlikteliğidir. Devletler kendi iradeleri ile ortak kural ve çıkarlara bağlı olduklarını kabul eder ve bu kural ve çıkarlar çerçevesinde ortak kurumlar oluştururlar (Bull, 1985: 13; Bull ve Watson, 1984: 1; Watson, 1987: 147). Devletlerin bir nevi toplum sözleşmesi ile uluslararası toplumu oluşturmalarındaki amaç, uluslararası toplumun kendisini korumak ve uluslararası toplumu oluşturan devletlerin her birinin varlığını ve varlığının devamlılı̆̆ını garanti altına almaktır. Ancak bu amaçlardan birincisi ikincisine üstündür. Üçüncü ve dördüncü amaç ise barışı sağlamak ve sosyal hayatın tüm çeşitlerinde görüldüğü üzere şiddeti sinırlamaktır. İşte tüm bu amaçların toplamı ve bu amaçlara ulaşmak için izlenen yollar uluslararası toplumda düzeni oluşturur (Bull, 1985: 16-20). Dolayısıyla uluslararası toplum teorisi bir üst otoritenin yokluğunda dahi devletler arasında iradi olarak oluşturulmuş bir toplum olduğunu ve bu toplumun düzenli olduğunu iddia etmektedir. İnsan iradi bir varlık olduğundan ve sosyal hayat içerisinde mevcudiyetini sağladığından, insanların kurmuş olduğu politik yapılar olan devletlerin de iradi varlıklar olacağı fikri uluslararası toplum düşüncesinin temelinde yatmaktadır (Bull, 1966; Wight, 1978: 105). Nas1l ki insanlar bir araya gelip toplumları oluşturuyorsa devletler de bir araya gelip uluslararası toplumu oluşturmaktadır.

Uluslararası topluma baktığımızda kolaylıkla gözlemlenebileceği üzere güdülen amaçlar birbirleri ile yakın ilişki içerisindedir. Örneğin uluslararası toplumun varlığının korunması onu oluşturan devletlerin varlığının korunmasına bağlıdır. Çünkü üyeleri var olmadan uluslararası toplum da var olmaz. Ancak yukarıda da belirtildiği üzere uluslararası toplumun bekası tek tek devletlerin bekasından daha önemlidir. İşte bu nedenledir ki barış sağlanırken ya da şiddet sınırlanırken bazı devletlerin varlığından vazgeçilebilir. Ancak, temel ilke, devletlerin içeride ve dişarıda sonsuz 
egemenlik hakkına sahip olmaları ve bu hakkın karşılıklı olarak tanınmasıdır (Wight, 1977: 135). İşte uluslararası toplumun üyelerinin birbirlerinin egemenliklerini tanıdığı ve bu toplumu üzerine inşa ettikleri prensibe müdahale etmeme prensibi denmektedir. Devletlerin egemenliğinin herhangi bir müdahale ile sınırlandırılmasının uluslararası toplumun varlığına zarar vereceği fikrinden hareket eden düşünce sistematiği ise çoğulcu (pluralist) uluslararası toplum olarak adlandırılmaktadır. İngiliz ekolünün önde gelen düşünürlerinden R.J. Vincent çoğulcu uluslararası toplumu yumurta kutusuna, bu toplumun üyeleri olan devletleri ise kırılgan kabuklu yumurtalara benzetmektedir. Uluslararası toplum bir yumurta kutusu vazifesi görerek hem her yumurta için izole bir alan oluşturmakta, hem de yumurtaların birbirlerine çarparak kırılmasını önlemektedir. Başka bir deyişle "uluslararası toplum müdahale etmek için değil, ayrık tutmak ve minder vazifesi görmek için vardır" (Vincent, 1995: 123).

Çoğulcu uluslararası toplum ve müdahale etmeme prensibi devletlerin varlığını, bağımsızlığını ve karşılıklı sınırlılığı korumaktayken (Slater ve Nardin, 1986: 86) adalet/düzen ikilemini de beraberinde getirmektedir. Çoğulcu uluslararası toplumun aksine dayanışmacı (solidarist) uluslararası toplum düşüncesi, adaletin düzene kıyasla ön planda olması gerektiğini iddia etmektedir. Bu düşünceye göre hak, asıl olarak insanlara aittir ve devletler onu insanlar adına kullanmaktadır. Dolayısıyla, çoğulcu uluslararası toplum görüşünün aksine devletlerin hukuku değil, insanların hukuku uluslararası toplumun kurucu prensibi olmalıdır. İnsanlar uluslararası toplumun nihai üyeleridir ve uluslararası toplum insan haklarını korumak ile görevlidir. $\mathrm{Bu}$ nedenle herhangi bir devlet kendi halkının insan haklarını ihlal ediyor ya da tümüyle elinden alıyor ise, uluslararası toplumun vazifesi bu devlete müdahale ederek adaleti sağlamaktır (Wheeler, 1992: 468).

Çoğulcu/dayanışmacı uluslararası toplum tartışması açık olduğu üzere normatif bir tartışmadır. Hakların asıl sahibinin kim ya da ne olduğu noktasından hareket eden bu tartışma, günümüz küresel uluslararası toplumunun aldığı/alacağı yön ve nasıl şekillenmesi gerektiği konuları üzerinden yürütülmektedir. Başka bir ifade ile, bu tartışma, doğal hukuk, pozitif hukuk tartışmasıdır. Çoğulculuk, Oppenheim'ın düşüncesinde olduğu gibi uluslararası hukukun sadece devletler arasındaki pratiklerden doğduğunu savunurken, dayanışmac1 uluslararası toplum görüşü, Grotius düşüncesindeki doğal hukuk anlayışını, yani uluslararası hukukun öncesiz ve sonrası olduğunu kabul etmektedir (Bull, 1966: 65-67). Barry Buzan (2001: 478), çoğulculuğun daha dar ve anarşik yapıda düzen problemine odaklanmış bir uluslararası toplum varsaydığını, dayanışmacılığın ise bunun aksine uluslararası toplumu daha geniş tanımladığını ve devlet ile onun vatandaşları arasındaki ilişkiyi bir "medeniyet standardı" olarak kabul ettiğini yazmaktadır. Günümüzde 
içerisinde bulunduğumuz uluslararası toplumun tam anlamıyla çoğulcu ya da dayanışmacı olduğunu ileri sürmek zordur. Ancak ele aldığımız modern uluslararası toplumun görece kısa tarihine göz attığımızda, henüz insani müdahale için bir standart oluşmamış olsa dahi, Soğuk Savaş dönemine göre daha dayanışmacı bir uluslararası toplumda yaşadığımız söylenebilir. Fakat şunu da belirtmek gerekir ki müdahale hala uluslararası toplumun bir istisnasıdır. Aslolan uluslararası toplumun ve dolayısıyla devletlerin varlığının ve devamının sağlanmasıdır.

Uluslararası toplumun üzerine inşa edildiği normlar bunlarla sınırlı değildir. Aynı zamanda düzeni sağlamanın kendisi bir norm olarak ele alınabilir. Devletler arasındaki toplumda asıl amaç düzen içerisinde varlığını devam ettirebilmektir. $\mathrm{Bu}$ nedenle düzen uluslararası toplumun başlıca karakteristiğidir. Uluslararası toplumda bir başka norm ise ahde vefa ilkesidir. Wight, (Bull, 1976: 104) uluslararas1 toplum fikri ile Grotius düşüncesi arasında paralellik kurar ve uluslararası toplumun "sözünü tutmak" normu sayesinde ayakta durduğunu iddia eder: "Bir üst otorite bulunmasa da devletler, yasal yükümlülükler dahi uygulayan moral ve kültürel bir birliktelik oluştururlar" (Wight, 1991: 7). Dahas1, Wight (1977: 33) sadece moral bir birliktelik değil aynı zamanda kültürel bir birlikteliğin de uluslararası toplumun karakteristiklerinden biri olduğunu iddia etmektedir.

Klasik İngiliz ekolü düşüncesi, bilinen insanlık tarihinde birden çok uluslararası toplum bulunduğunu kabul etmektedir (Wight, 1977 ve 1991; Bull, 1985; Watson, 1992; Gong, 1984). Ekole göre Uluslararası İlişkiler çalışmalarının ana amacı, bu farklı uluslararası toplumların kural, kurum ve değerlerini birbirleri ile karşıllaştırarak işleyiş̧lerini anlamaktır (Wight, 1977: 21-45; Bull, 1977: 16; Watson, 1990: 100). Bu farkl1 uluslararas1 toplumlar aynı anda var olabileceği gibi farklı zaman periyotlarına da yayılmış olabilirler. Günümüzde bazı bölgesel uluslararası toplumlar ${ }^{1}$ var olsalar dahi, modern uluslararası toplum tek ve küresel olarak kabul edilmektedir. Başka bir deyişle, çağdaş uluslararası toplum tüm dünyaya yayılmıştır ve tekildir. Her ne kadar yayılması konusunda çeşitli görüşler bulunsa da, çoğunlukla günümüz uluslararası toplumunun 17. yüzyılda Avrupa'da doğduğu ve 18. yüzyıldan itibaren tüm dünyaya yayıldığı kabul edilmektedir (Bull ve Watson, 1984; Gong, 1984; Buzan, 2010).

Uluslararası toplum dediğimiz zaman, günümüzde varlığını sürdüren tüm devletleri kapsayan ve kendine özgü kurum ve kuralları bulunan küresel uluslararası toplumu kastetmekteyiz. Özetle, bu çalışma İngiliz ekolünün temel varsayımlarını takip ederek, uluslararası ilişkilere toplumsal bir perspektiften

\footnotetext{
${ }^{1}$ Bölgesel uluslarararası toplumlar, küresel uluslararası toplumun birer alt kümesidirler.
} 
bakmakta ve uluslararası ilişkilerin toplumsallık arz ettiğini ve bu yüzden uluslararası toplumun var olduğunu kabul etmektedir. Bu uluslararası toplum modern çağda küresel olmuş, yani tüm dünyaya nüfuz etmiştir. Uluslararası toplumun öncelikli amaçları, toplumun kendisi ve onu oluşturan devletlerin varlığının sürdürülmesi, şiddetin sınırlanması ve göreli olarak barışın, düzenin ve/veya adaletin sağlanmasıdır. Diplomasi, büyük güçler yönetimi, güçler dengesi, savaş ve uluslararası hukuk gibi kurumlar bu amaçlar doğrultusunda çalışarak uluslararası toplumun gerçekliğini meydana getirirler. Bu kurumlar hem gündelik uluslararası siyasette hem de uluslararası toplumun kriz anlarında işlemektedir. Doğal olarak uluslararası toplumun kurumlarının işlerliği kriz anlarında daha görünür olmaktadır.

\section{Uluslararası Toplumun Kurumları Nasıl Çalışıyor? Suriye Krizi Örneği}

Belirttiğimiz üzere modern uluslararası toplum insanlık tarihi boyunca ortaya çıkmış yegane uluslararası toplum değildir. İnsanların farklı zamanlarda kurduğu farklı siyasi yapılar, her ne kadar ulus devlet olmasalar dahi, çeşitli uluslararası toplumlar oluşturmuştur. $\mathrm{Bu}$ nedenle her uluslararası toplumun kendisine özgü kurum ve kuralları vardır. Bu kurum ve kurallar o uluslararas1 toplumun yapısını ve işleyişini de belirler. Wight'ın (1978: 111) deyişiyle, "uluslararası toplumun kurumları onun doğasına göredir." Örneğin, 18. yüzyılda Osmanl1-Avrupa uluslararası toplumunun en önemli kurumlarından biri kapitülasyonlardı. Dini festival ve ortak mabetler de Yunan şehir devletlerinin oluşturduğu uluslararası toplumun vazgeçilmez kurumları olarak nitelendirilebilirler (Wight, 1977: 47). Bu ve benzer örnekler çoğaltılabilir, neticede uluslararası toplum kavramının kurumları ne öncesiz ve sonrasız, ne de değişmezdir. Her ne kadar bazı kurumlar birbirleri ile parallellik gösterseler de, diplomasi kurumunun ulaklar ya da geçici sefirler vasitasıyla işletilmesi gibi, her uluslararası toplum kendine has kurumlar geliştirmiştir. Dolayısıyla küresel uluslararası toplumun kurumları da kendisine özgüdür.

Bull (1985: 74), uluslararası toplumun kurumlarının mutlaka bir teşkilat biçiminde olması gerekmediğini, ortak çıkarlara ulaşma amacı etrafında şekillenen alışkanlıklar ve icraatlar bütününün de "kurum" olarak adlandırabileceğini vurgulamakta ve küresel uluslararası toplumun kurumlarını; büyük güçler yönetimi, güçler dengesi, diplomasi, uluslararası hukuk ve savaş olarak tanımlamaktadır. O halde NATO (North Atlantic Treaty Organization), Birleşmiş Milletler (BM), İslam İşbirliği Teşkilatı, Afrika Birliği gibi yönetsel yapılar uluslararası toplumun birincil kurumları değil, ikincil kurumlarıdır. Birincil kurumlar "uluslararası toplumun üyelerinin sahip olduğu değerleri içerisinde şekillenen uzun ömürlü, muteber pratikler ile gelenek ve 
alışkanlıklardır” (Buzan 2004: 181-7). İkincil kurumlar ise birincil kurumlardan türerler ve onlara göre daha kısa ömürlü ve değişkendirler. Örneğin büyük güçler yönetimi uluslararası toplumun birincil kurumu iken, Birleşmiş Milletler Güvenlik Konseyi (BMGK) ikincil bir kurumdur. Bir diğer örnek olarak, 1982 tarihli Deniz Hukuku Sözleşmesinin uluslararası hukuktan türemiş bir ikincil kurum olması gösterilebilir. Sonuç olarak kurum dediğimiz şey, belirli alışkanlık ve geleneklerin tekrarlanması sonucu oluşmuş, uluslararası toplumun amaçlarına ulaşmaya ve düzeni tahakkuk etmeye yarayan pratiklerdir.

Küresel uluslararası toplumun kurumlarını İngiliz ekolünden farklı isimler farklı şekillerde sıralamışlardır. Örneğin Wight (1978: 111) bu kurumları diplomasi, ittifaklar, teminatlar (ya da ahde vefa) savaş ve tarafsızlık olarak sayarken; Alan James (1978: 97) uluslararası hukuk, egemenlik ve diplomasinin, Mayall (2000: 149-150) ise güçler dengesi, uluslararası hukuk ve diplomasinin uluslararası toplumun kurumları olduğunu söylemektedirler. $\mathrm{Bu}$ çalışmada, uluslararası topumun işlerliğini göstermek amaciyla Bull'un tanımladığı kurumlar ele alınmaktadır. Bu seçim, kurumlar ve düzen arasındaki ilişkiyi en iyi açıklayan düşünürün Bull olmasından kaynaklanmaktadır. Dahası, Bull'un tanımladığı kurumlar, diğer isimlerin tanımladıklarının rafine bir hali olarak nitelenebilir. Bull, Anarşik Toplum (1985) isimli eserinde, kurumlar vasıtasıyla, bir üst otoritenin olmadığı uluslararası alanda düzenin nasıl sağlandığını ve kaosun nasıl önlendiğini net bir biçimde, kapsayıcı kurumlar tanımlayarak göstermiştir.

$\mathrm{Bu}$ çalışmada ele alınan temel ve birincil kurumlar, yani büyük güçler yönetimi, güçler dengesi, diplomasi ve uluslararası hukuk uluslararası toplumun işlerliğini göstermektedir. Bu kurumlar tek tek ya da hep birlikte uluslararası toplumun amaçlarını gerçekleştirmede ve düzenin/adaletin sağlanmasında rol alırlar. Başka bir deyişle uluslararası toplumun kurumlarının hepsi aynı anda ve aynı amaca yönelik olarak çalışmak zorunda değildir. Örneğin, savaş da Bull (1985: 184-188) tarafindan uluslararası toplumun bir kurumu olarak tanımlanmıştır. Özellikle uluslararası hukukun zorla uygulanması ve güçler dengesinin tahsisine hizmet eden savaş, uluslararası toplumun Suriye krizinde işletmediği kurumlardan birisidir. Çünkü savaş, Bull'un da (1985: 187) belirttiği üzere devletlerin bir politika aracı olduğu kadar, uluslararası toplumun varlığına da bir tehdittir. Bu nedenle savaş kurumu çalışmaya dahil edilmemiştir.

Bazı durumlarda güçler dengesi kurumunun işlemesinin sonucunda göreli barışın sağlandığı bir örnekte uluslararası hukuk çalışmamış olabilir. Ya da büyük güçler yönetimi çoğu zaman savaş kurumunun işlemesini önler. $\mathrm{Bu}$ sebeple tüm kurumların aynı anda aynı amaca yönelik olarak çalışmamış olması uluslararası toplumun işlerliğini yitirdiği anlamına gelmez. Ancak 
egemenlik çoğu zaman, tüm bu kurumların varlığına ve işlemesine olanak sağlayan temeli sunar (Wight, 1977: 135; Bull, 1985: 71; Bull, 1979). Kurumların devlet davranış pratiğinden kaynaklanmasının asıl sebebi de budur. Uluslararası toplum kuramında atlanmaması gereken nokta, özellikle Bull'un tanımladığı küresel uluslararası toplumun ve kurumlarının idealize edilmiş olduklarıdır. $\mathrm{Bu}$ durum teori yapma eyleminin doğasında olduğundan, yani teorize etme eylemi büyük ölçüde bir soyutlama olduğundan, gayet doğaldır (Yurdusev, 2005: 157-158). Çalışmanın devamında bu noktaya kadar incelenen uluslararası toplum teorisinin gerçek dünyada nasıl karşıllk bulduğu Suriye krizi örnek olayı ile gösterilecektir.

Suriye'deki kriz, 2011 Mart'ında Beşar Esad yönetimindeki iktidar ve muhalif güçler arasındaki çatışmalarla başlamış ve üç yıldan fazla süredir devam etmektedir. Krizin sonucu olarak on binlerce kişi hayatını kaybetmiş, evsiz kalmış ya da ülkedeki şiddet ortamından kaçarak Türkiye, Irak ve Lübnan gibi komşu ülkelere göç etmek zorunda kalmıştır. Aslında Suriye'de yaşananlar, Arap Baharı olarak adlandırılan halk hareketlerinin bir parçasıdır. Aralık 2010'da Tunus'ta hükümet karşıtı gösterilerle başlayan halk isyanları, kısa sürede Libya, Yemen, Mısır, Cezayir ve Ürdün gibi pek çok Ortadoğu ve Kuzey Afrika ülkesine sıçramış ancak Suriye'de süreç bu ülkelerden çok daha farklı şekilde cereyan etmiştir. Zeynel Abidin Bin Ali, Muammer Kaddafi ve Hüsnü Mübarek gibi güçlü diktatörlerin bile değişim rüzgarına karşı koyamadığı ve iktidarlarını kaybettikleri bu süreçte, Esad rejimi, özellikle Rusya, Çin ve İran gibi bölgesel ve küresel müttefiklerin desteğinin de etkisiyle ayakta kalmayı başarmıştır.

Pek çok Kuzey Afrika ve Ortadoğu ülkesine benzer şekilde, Suriye'de de halk 2011 Mart'ında gösterilere başlamış ve gösteriler kısa sürede tüm ülkeye yayılmıştır. Kriz, ülkeyi uzun süredir yöneten Baas Partisi ve Beşar Esad karşı1tlı̆̆ına dönüşmüş ve Suriye halkı Esad yönetiminden reform talebinde bulunmuştur. Ancak Suriye'deki rejimin yaptığı oldukça küçük çaplı reformlar Suriye halkını tatmin etmeye yetmemiş ve Esad yönetimi gösterileri güç kullanarak bastırmaya çalışmıştır. Süreç içerisinde ordu destekli Suriye yönetimi ile muhalifler arasında yaşanan yoğun silahlı çatışmalar iç savaşa yol açmıştır. Muhaliflerin birçok kentte yönetimi ele almasının ardından Esad rejimi şiddeti artırmış ve Ağustos 2013'te sivil halka karşı kimyasal silah saldırısıyla tekrar üstünlüğü ele geçirmiştir. Bu saldırı sonrasında uluslararası toplum, Suriye'ye karşı yapılacak müdahale konusunda bölünmüş ancak Amerika Birleşik Devletleri (ABD) başkanı Obama'nın bu konuda Kongre desteği aradığı esnada yapılan Rusya'nın teklifini Suriye'deki rejimin kabul etmesi üzere, ABD müdahale fikrinden vazgeçmiştir (Buçukçu, 2011: 7-9; Hürriyet, 10 Eylül 2013; Hürriyet, 15 Eylül 2013). 
Açıkça gözlemlenebileceği üzere, Suriye krizi, Arap Baharının devamı niteliğinde olmasının da etkisiyle daha başladığı andan itibaren uluslararası kimlik kazanmış bir olayıdır. Krizin çabuklukla uluslararası toplumun gündeminin ilk sırasına oturmasının başlıca sebepleri arasında Ortadoğu'nun dünya siyasetinin en hassas bölgelerinden olması, ABD, Rusya, Çin, Avrupa Birliği ( $\mathrm{AB}$ ) gibi küresel aktörlerin bölgeye olan ilgisi ve bölgesel güçlerin güvenlik endişeleri ile Suriye'deki en küçük değişimlere bile duyarlı olmaları sayılabilir. Uluslararası toplum teorisi açısından Suriye krizinin kurumlar mekanizmasını çalıştıran noktalar üç adımda açıklanabilir; birincisi, Suriye'deki durum, uluslararası toplumun temel amaçlarından olan şiddetin sınırlanması ve göreli barışın sağlanmasına tehdit oluşturmaktadır. İkincisi, Suriye'nin devlet olarak ortadan kalkması, başka bir deyişle egemenliğini yitirmesi ya da dünya siyaset sahnesinden silinmesi, uluslararası toplumun "üyelerin bekalarını sağlama" amacıyla ters düşmektedir (Northedge, 1981: 12). Üçüncüsü, Suriye'ye müdahalenin gündeme gelmesi uluslararası toplumun çoğulcu mu yoksa dayanışmacı bir yol izleyeceği sorusunu gündeme getirmiştir. Bu durum, aynı zamanda, hem güçler dengesi hem de büyük güçler yönetimi mekanizmalarını harekete geçirmiştir.

\section{A. Suriye Krizinde Büyük Güçler Yönetimi}

Büyük güç kavramı disiplinde o kadar büyük yer tutmaktadır ki uluslararası ilişkilerin tarihini büyük güçler arasındaki ilişkilerin tarihi olarak dahi tanımlayabiliriz (Ranke, 1981: 122-123). Büyük güçlerin Suriye krizinde de etkin rol alması bu nedenle şaşırtıcı değildir. Uluslararası İlişkilerde büyük güçler dediğimizde belirli bir zaman diliminde nüfuzu en yüksek olan aktörleri kastetmekteyiz (Griffiths ve O'Callaghan, 2002: 132). Ranke'nin (1981: 140) de belirttiği üzere "diğer güçler ittifak halinde olsa dahi büyük güç bu ittifaka karşı duruş sergileyebilmelidir." Ayrıca, "büyük gücün hususi hak ve görevlere sahip olduğu hem kendisi tarafindan hem de uluslararası toplumdaki diğer devletler tarafindan kabul görmelidir" (Bull, 1980: 437). Ian Clark bu durumu uluslararası toplumda meşruiyet sorunsalı ile açıklamaktadır. Clark'a göre uluslararası toplumda hegemonya ve meşruiyet birbirleri ile çok yakın ilişki içerisindedirler. Yani büyük güç dediğimiz aktör, ancak onun büyük güç olduğunu kabul eden ikincil derecedeki ya da daha küçük aktörlerin varlığı ile meşruiyet kazanır (Clark, 2003, 2007, 2009 ve 2011).

Büyük güçler yönetimi kurumunun bir diğer özelliği ise uluslararası toplumda büyük güç dediğimiz aktörlerin her zaman çoğul olarak ele alınmasıdır. Başka bir deyişle, uluslararası toplumda her zaman iki ya da daha fazla büyük güç bulunmalıdır ki "büyük güçler yönetimi” kurumundan bahsedebilelim (Bull, 1985: 200). Bunun başlıca sebebi normatiftir. Özellikle 
güçler dengesi ile birlikte düşündüğümüzde, İngiliz ekolünün klasik düşünürleri tarafindan (Bull, 1985; Butterfield, 1966) uluslararas1 toplumun anti-hegemonik bir karakterde olması gerektiği savunulmuştur. Eğer uluslararası toplumda tek bir büyük güç var ise o uluslararası toplumun bir çeşit imparatorluk ya da tahakküm ile sonuçlanması çoğunlukla kaçınılamaz (Wight, 1977: 26, 43). Ancak Clark (2009 ve 2011), daha sonra hegemonyanın da uluslararası toplumda var olabileceğini iddia etmiştir. Bull'a göre (1985: 207) büyük güçler birbirleri ile güç dengesini sağlayarak, krizleri ve savaşları sınırlayarak ya da bunlardan tamamen kaçınarak uluslararası toplumun düzen sağlayıcı bir kurumu olarak hareket ederler. Büyük güçlerin birbirleri ile ilişkilerini yönetmeleri güçler dengesinin diplomasinin işleyişine mahal vermeyecek bir biçimde bozulmasını engellemektedir (Wight, 1966: 165). Suriye krizinde de küresel uluslararası toplumun büyük güçlerinin yani özellikle ABD, Rusya, $A B$ ve Çin'in birbirleri ile ilişkilerini yöneterek uluslararası toplumun varlığını ve düzenini koruduğunu net bir biçimde görmekteyiz. Batılı güçlerin daha müdahaleci tutum takındığı Suriye krizinde, Rusya ve Çin ekseriyetle BM kararlarına muhalefet ederek ABD ve AB'yi dengelemiştir.

$\mathrm{Bu}$ iki gücün özellikle krizin ilk iki yılında Suriye ile ilgili kararların çoğuna karşı çıkması sonucunda $A B D$ ve $A B$ ülkelerinin $B M$ gündemine getirdiği kararların çıkması mümkün olmamıştır. Aslında BMGK'daki karar alma sürecinin kendisi güçler dengesi ilkesinin yanı sıra, büyük güçler yönetiminin doğrudan bir sonucudur. Beş daimi, on seçilmiş ve geçici üyesi olan BMGK, İkinci Dünya Savaşı sonrası uluslararası barış ve güvenliği sağlamak amacıyla kurulan BM'nin en önemli organıdır ve kararları tüm üye ülkeler için bağlayıcı nitelik taşımaktadır. Konseye sunulan bir önergenin kabulü için 9 üyenin oyu yeterlidir ancak ABD, Rusya, Çin Halk Cumhuriyeti, Fransa ve Birleşik Krallık'tan oluşan BMGK'nın beş daimi üyesinin veto hakkı bulunmaktadır. İkinci Dünya Savaşı'nın galiplerini temsil eden bu beş üyeden birinin dahi veto ettiği bir kararın kabul edilmesi mümkün değildir.

Ekim 2011'de, muhalif eylemlere karşı uygulanan baskı dolayısıyla Suriye'ye karşı daha sert adımlar atılmasını öngören ve Suriye'yi gerekli olması durumunda yaptırımlarla karşılaşabileceği konusunda uyaran karar tasarıs1, Rusya ve Çin'in veto etmesi sonucunda reddedilmiştir. Rusya, metinde Suriye'nin iç işlerine karışılmayacağına ve dolayısıyla ülkeye müdahalede bulunulmayacağına dair bir ifade olmadığını belirtirken, Çin de Suriye'nin içişlerine müdahale fikrine karşı olduklarını vurgulamıştır (BBC Türkçe, 5 Ekim 2011). Şubat 2012'de BMGK'ya sunulan ve ülkedeki şiddetin sona ermesi çağrısında bulunarak Suriye rejimi tarafından yapılan insan hakları ihlallerini kınayan başka bir karar tasarısı bir kez daha Rusya ve Çin'in vetosu nedeniyle kabul edilememiştir. Veto kararı ile ilgili olarak Rusya ve Çin 
tasarının muhalifler ve iktidar arasında dengeli bir tutum almadığını savunmuştur (Ntvmsnbc, 4 Şubat 2012).

Rusya ve Çin'in BMGK'daki üçüncü vetosu, Suriye yönetiminin ülkedeki ağır silahların kullanımına son vermemesi ve BM Sözleşmesi’nin yedinci bölümüne bağlı kalmaması halinde ${ }^{2}$ (askeri olmayan) yaptırımlarla karşılaşacağını öngören karar tasarısına karşı olmuştur. BM'de görüşülen bir tasarıy1 üç kez veto ederek BMGK tarihine geçen Rusya ve Çin, siyasi ve ekonomik yaptırımlar içeren bu karar tasarısının askeri yaptırımların önünü açacağından endişe etmiştir (Al Jazeera Turk, 19 Temmuz 2012; Radikal, 19 Temmuz 2012). Rusya ve Çin son olarak, Suriye'de işlenen savaş suçları ile insan hakları ihlallerinin Uluslararası Ceza Mahkemesi'ne (UCM) sevk edilmesini öngören karar tasarısını da veto etmiştir (Anadolu Ajansı, 22 Mayıs 2014).

Rusya, ABD, Çin ve AB gibi büyük güçlerin Suriye krizi konusundaki farklı görüşleri, krizin yönetilme şeklini ve sürecini önemli şekilde etkilemiştir. Suriye'deki kriz konusunda Rusya ile ABD arasındaki farklı görüşlere değinmesi ve Rusya'nın konumunu vurgulaması açısından Putin'in 11 Eylül 2013 tarihinde New York Times'ta yayınlanan makalesi oldukça büyük önem arz etmektedir. Putin direk olarak Amerikan halkına ve siyasetçilerine seslendiği bu makaleye, BM'deki karar alma sürecinin ve beş daimi üyeye tanınan veto hakkının barış ve savaşı ilgilendiren konuların oybirliği ile alınması gerekliliğinin bir sonucu olduğunu vurgulayarak başlamıştır. Makalede siklıkla uluslararası toplumun özellikle uluslararası hukuk ve diplomasi gibi kurumlarının işletilmesinin önemine değinen Putin, Washington'ı tek taraflı bir karar almanın muhtemel sonuçlarına karşı uyarmış ve böylesi bir eylemin uluslararası hukuk ve denge sisteminin sonunu getireceğini vurgulamıştır (New York Times, 11 Eylül 2013). Belirtilmelidir ki, kimyasal silah kullanılması sonucunda Suriye'ye karşı (askeri) bir müdahale yapılması gerektiğini savunan Obama bile, bunu tek taraflı bir ABD müdahalesi şeklinde değil, BM kararı ile yapmaya çalışmıştır. Bu durum, Suriye krizinde büyük güçler yönetiminin oldukça bariz bir örneği niteliğindedir. $\mathrm{Bu}$ iki büyük gücün liderleri sadece uluslararası toplum ve kurumlarını söylemlerine dahil etmemiş aynı zamanda onları işletmeye çalışmışlardır; bu yüzden uluslararası toplum sadece teoride değil, uluslararası politikanın aktörleri tarafından algılandığı üzere gerçekte de mevcuttur.

${ }^{2}$ BM Antlaşması'nın yedinci bölümü, barışın tehdidi, bozulması ve saldırı eylemi durumunda alınacak önlemler ile ilgilidir ve 39. ve 51. Maddeler arasını kapsamaktadır. BM antlaşmasının bu bölümü, uluslararası toplumun varlığını korumak, göreli barışı sağlamak ve şiddeti sınırlamak amaçlarına hizmet etmektedir. 
Tek taraflı bir askeri müdahalenin ya da yaptırımın Suriye'ye uygulanamayacağını, Rusya ve Çin'in BMGK'nın bağlayıcı kararlarına muhalefeti açıkça göstermiştir. Bu iki ülkenin vetolarının en önemli noktası, $A B D$ ve Suriye'ye müdahaleyi destekleyen diğer ülkelere uluslararası toplumun tek elden yönetilemeyeceğini göstermesidir. Büyük güçler yönetimi kurumu bu sayede hem bir üyesinin varlığını hem de daha sonraki müdahalelere zemin hazırlayacak bir kararı önlemiştir. Dolayısıyla uluslararası toplum, büyük güçler yönetimi kurumu aracıllı̆̆ ile düzen/adalet dengesi bağlamında düzen lehine işlemiştir.

Büyük güçler yalnızca birbirleri ile ilişkilerini düzenleyerek uluslararası toplumun amaçlarına ve düzene hizmet etmezler. Aynı zamanda uluslararası toplumdaki üstün pozisyonlarını toplumun geri kalanı ile ilişkilerinde de gösterirler. Bölgesel olarak baskınlıklarını tek taraflı gösterebilecekleri gibi, diğer büyük güçler ile etki alanları üzerinde anlaşabilir, çeşitli bölgelerde müşterek hakimiyet vasitasıyla hareket edebilirler (Bull, 1985: 207). Suriye krizinde de bilhassa ABD ve Rusya arasında etki alanları konusunda bir mücadele yaşanmış, ABD her ne kadar ilk bakışta Ortadoğu coğrafyasında fazlasıyla etkin görünse de, Suriye'nin halen Rusya'nın etki alanı olduğunu kabul etmek durumunda kalmıştır. Neticede Suriye sınırları içindeki Tartus, Rusya'nın Akdeniz'deki tek deniz üssüdür ve Rusya'nın böyle bir üsten vazgeçmesi çok olası değildir (Doster, 2012: 34). ABD, özetle, krizin derinleştiği, insani kayıpların had safhaya ulaştığı ve kimyasal saldırıların yaşandığı günlerde yoğun bir biçimde müdahale edilmesi konusunda pozisyon almış ancak büyük güçler yönetimi kurumunun birbirinin etki alanlarını tanıma prensibinin işletilmesi sonucunda uluslararası toplumda düzen korunmuştur.

Rusya ve ABD müşterek hakimiyet vasıtası ile de Suriye krizinde büyük güçler yönetimi kurumunu işletmişlerdir. Uluslararası hukuk kurumu başlığında altında da işleneceği üzere Suriye'ye müdahale Rusya ve ABD'nin kimyasal silahların imha edilmesi hususunda anlaşması ile engellenmiştir. Suriye yönetiminin Guta kentinde 21 Ağustos 2013'te sivil halka karş1 kimyasal silah kullandığına dair iddialar BM gündemine taşınmış ve iddiaları incelemek üzere bir $\mathrm{BM}$ araştırma misyonu oluşturulmuştur. $\mathrm{Bu}$ misyonun hazırlayıp BM Genel Sekreteri Ban Ki-moon'a sunduğu 16 Eylül 2013 tarihli raporda, iktidarın bu kentte çocuklar da dahil olmak üzere sivil halka karşı görece yoğun bir şekilde kimyasal silah kullandığını gösteren "açık ve ikna edici" delillerin olduğunu belirtmesinin ardından yaklaşık on gün sonra, BM Genel Kurulu bu raporu baz alarak 2118 nolu karar tasarısını hazırlamıştır. Kalaycı'nın da belirttiği üzere, (28 Eylül 2013) krizin başlamasından itibaren üçüncü defa BMGK'ya gelen karar tasarısı, Suriye'de kimyasal silahların kullanıldığının kesinleşmesinin ardından tüm devletlerin "evet" demesi sonucunda kabul edilmiş ve kararın oybirliğiyle alınması, "uluslararası 
toplumun konuya gösterdiği duyarlılığı ifade ettiği şeklinde yorumlanmıştır." Suriye'de kimyasal silah kullanımını kınayan kararda, kimyasal silah kullanımının uluslararası barış ve güvenliği tehdit ettiği ve 21 Ağustos 2013 tarihli saldırının uluslararası hukukun ihlali anlamına geldiği belirtilmektedir. Diğer bir deyişle BM aracılı̆̆ ile büyük güçler yönetimi uluslararası toplumun amaçlarından olan şiddetin sınırlanması ilkesine yönelik hareket etmiş bulunmaktadır. ${ }^{3}$

\section{B. Suriye Krizinde Güçler Dengesi}

Suriye konusunda bölgesel ve küresel güçler arasındaki görüş farklılıkları güçler dengesi kurumunun sorunsuzca işlemesine yol açmıştır. Bu süreçte, $A B D$ ve $A B$ 'nin başını çektiği Batılı güçler ile Sünni Arap Devletleri ve Türkiye, rejim değişikliği hatta gerekli olması durumunda müdahale taraftarı iken, Rusya ve Çin, muhalif güçler ve mevcut rejim arasındaki sorunların Suriye'nin iç meselesi olduğunu savunarak, Suriye'ye karşı güç kullanımına karşı çıkmış ve bu tür kararları BMGK'da veto etmiştir. Bu ülkelerin her birinin Suriye kriziyle ilgili farklı tutumlar takınmalarının çeşitli tarihi, siyasi ve stratejik sebepleri bulunmakla birlikte bu farklı aktörlerin uluslararası toplumda güçler dengesi kurumu çerçevesinde hareket ettikleri açıkça görülmektedir.

Güçler dengesi kavramı adından da anlaşılacağı üzere bir sistemdeki güçlerin karşılıklı kamplara eşit biçimde dağılımını ifade etmektedir. En basit tanımı ile, bir güç fazlası ile büyüdüğünde, diğerleri ona karşı ittifak oluşturarak onu dengelerler (Wight, 1978:169). Herbert Butterfield (1966: 132) güçler dengesini Newton'un yerçekimi prensibine benzeterek, sistemdeki her gücün adeta bir yerçekimi etkisi ile birbirini dengeleyecek pozisyon aldığını vurgulamaktadır. Ancak güçler dengesi mekanik değil, iradidir; bu nedenle güçler dengesini etkileyen ulusal, moral ve diplomatik etmenler mevcuttur (Tanrısever, 2007: 57). Bull da (1985: 103) güçler dengesinin algısal dahi olabileceğini ve bir denge oluştuğuna dair inancın güçler dengesi yaratabileceğini savunmaktadır.

Klasik İngiliz ekolü teorisinde güçler dengesi, eşit güç dağılımı anlamına gelmektedir. Bull (1985: 106) ve Jackson (2000: 138) gibi çoğulcu uluslararası toplum yaklaşımına sahip isimler güçler dengesi kavramından hiç bir tarafin diğerine üstün olmadığı tam bir dengeyi kastetmektedirler. Ancak şunu da

\footnotetext{
${ }^{3}$ Ayrıntılı bilgi için bkz. United Nations Security Council Resolution 2118 (27 Eylül 2013), S/RES/2118, http://www.un.org/en/ga/ search/view_doc.asp?symbol= S/RES/2118(2013) (05.06.2014).
} 
belirtmek gerekir ki tam bir güçler dengesine ne kolaylıkla ulaşılabilir, ne de farklı güçlerin büyüklükleri net olarak ölçülebilir. Dahası, ele aldığımız teori sadece materyal güce değil, o gücün nasıl algılandığı ve gücün moral tutumu gibi faktörlere de önem verdiğinden, uluslararası toplumda çoğu zaman eşit bir güçler dağılımından bahsetmek oldukça zordur. Dolayısıyla, günümüz uluslararası toplumunun işleyişinde bir tarafi belirli bir harekette bulunmaktan alıkoymaya yetecek kapasiteye sahip olan karşı taraf, güçler dengesi sağlamış olarak kabul edilebilir. Çalışmanın ele aldığı Suriye krizinden örnek verecek olursak, bir tarafta ABD ve müttefikleri, diğer yanda Rusya, Çin ve müttefikleri bire bir güç dengesini maddi ve maddi olmayan biçimde sağlamıyor olabilirler ancak, kriz süresince her iki taraf da birbirlerini kendi başlarına eylemden alıkoymuşlardır.

Bull (1985: 106-112) ve Wight (1991: 166-167) benzer şekilde uluslararası toplumda güçler dengesi kurumunun işlevlerini sistemin tekil bir imparatorluğa dönüşmesini engellemek, yerel dengelerin işleyişinin de yardımı ile devletlerin bekalarını korumak ve uluslararası toplumun diğer kurumlarının çalışmasına zemin hazırlamak olarak sıralamaktadırlar. Haliyle uluslararası toplumun bu kurumu büyük güçler yönetimi ilkesi ile yakın ilişki içerisinde çalışmaktadır. Suriye krizinde de güçler dengesi kurumunun çalışması, birden fazla gücün birbirlerini dengelemesiyle güçlerin tek başlarına harekete geçmesini engellemiş ve bu kurum uluslararası toplumun temel ilkelerinden olan devletlerin varlığının korunması, göreli barışın sağlanması ve şiddetin sınırlanması prensiplerine hizmet etmiştir.

Güçler dengesi kurumu, ABD’nin “dünyanın polisi” gibi algılanmasına karşın Suriye krizinde tek taraflı hareket etmesinin önüne geçmiştir. Tahmin edileceği üzere, ABD'nin, Rusya'nın Ortadoğu'daki en önemli müttefiklerinden biri olan Suriye ile ilişkileri çok iyi değildi (Akgün, 2012: 1213). Ancak ABD'nin Suriye politikası, sanıldığının aksine her zaman müdahale üzerine kurulu olmamıştır. Obama, krizden yaklaşık bir sene sonra gerçekleşen bir basın toplantısında, ABD'yi müdahale etmemekle suçlayanların ve Libya ile Suriye örneklerini karşılaştıranların savaşın maliyetini düşünmeleri gerektiğini ifade etmiştir:

"Suriye'de yaşananlar yürekler acısı ve şoke edicidir ve burada uluslararası toplumun Esad rejimine karşı harekete geçtiğini görmektesiniz... Öte yandan, bizim için tek taraflı bir askeri eylemde bulunmak veya bazılarının öne sürdüğü gibi basit bir çözüm olduğunu düşünmek hatadır. Libya'da olan BM şartları çerçevesinde uluslararası toplumu harekete geçirmemiz, ve Arap devletleri ile tam bir bölgesel işbirliği sağlamamızdır. Burada göreceli olarak kısa bir zamanda etkili sonuç alacağımızı biliyorduk. Ancak bu çok daha karmaşık bir durumdur... Her sorun karşısında ordumuzu harekete geçirmemiz 
geçmişte doğru olmadığ1 gibi şimdi de doğru olmayacaktır" (White House, 6 Mart 2012).

Ancak, Obama, Mart 2013'te Suriye'ye referans yaparak kimyasal silah kullanımının askeri müdahaleye yol açabilecek bir "kırmızı çizgi" ya da "oyun değiștirici” olduğunu söylemiştir (Black, 2013). Gerçekten de Obama'nın kırmızı çizgisi olduğunu söylediği kimyasal silahların kullanımı sonrasında Suriye'ye yapılacak kısıtlı bir askeri müdahale konusunda Kongre'nin desteğini almaya çalıştığını görmekteyiz. Hem yukarıda değinilen sebeplerden hem de güçler dengesinden ötürü başlangıçta $\mathrm{ABD}$ 'nin Suriye politikasının daha "düzen" taraftarı olduğunu söyleyebiliriz. Obama'nın konuşması uluslararası toplumun kurumlarına yapılan vurguyu göstermesi açısından oldukça önemlidir. Obama bu konuşmasında hem genel güçler dengesini hem de Arap ülkelerinin de desteğini alarak bölgesel güçler dengesini gözettiğinin üzerinde durmaktadır. Üstelik BM desteğini arkasına almak istediğini de belirterek, büyük güçler yönetimi kurumunu da göz ardı etmemiştir. Obama'nın bu konuşmasından, ayrıca, krizin ilk zamanlarında ABD'nin de Rusya gibi düzenin tarafında olduğunu ancak kimyasal silah kullanımı sonrasında adaleti vurgulamaya başladığını görüyoruz. Başka bir deyişle ABD, Suriye krizinde düzen ve adalet arasında gidip gelmektedir.

Güçler dengesi kurumu ABD gibi Rusya'yı da tek taraflı hareket etmekten alıkoymuştur. Suriye ile Rusya'nın Sovyetler Birliği döneminden süregelen yakın ilişkileri olduğu ve Suriye'nin özellikle sahip olduğu jeostratejik konum nedeniyle Rusya için oldukça önemli bir ülke olduğu bilinmektedir. Soğuk Savaş döneminde Ortadoğu'da nüfuzunu artırmak isteyen Sovyetler, Suriye'yi, Ortadoğu'daki müttefiki olarak benimsemiştir. Bu dönemde Sovyetler, ABD'nin Sovyetler'e karşı uyguladığ 1 çevreleme politikasının etkisini kırmak ve Doğu Akdeniz'de varlığını devam ettirmek istemekteydi. Suriye'nin Rusya için önemi, Soğuk Savaş'ın bitmesinin ardından da devam etmiş, Rusya Suriye krizi konusunda Esad rejimini destekleyerek, Batılı güçlerin müdahale planlarına karşı çıkmıştır (Yazıcı, 2012: 40-43). Rusya'nın Suriye ile yaptığı askeri işbirliği anlaşmaları ve Tartus'ta bulunan Rus deniz üssü de bu konuda belirleyici rol oynamıştır.

Güçler dengesi kurumunun işleyişinin bir neticesi olarak Moskova, Suriye politikasını izlerken Esad yönetimini aleni bir şekilde desteklemek yerine, sürekli olarak uluslararası hukuka ve Suriye'nin toprak bütünlüğüne vurgu yapmıştır. Örneğin, Esad rejiminin sivil halka karşı kimyasal silah kullandığının kesinleşmesinin ardından ülkenin kimyasal silahlardan arındırılması üzerine sürdürülen diplomasi trafiği esnasında $A B D$, İngiltere, Fransa ve Türkiye gibi güçler BM Şartı'nın askeri müdahaleyi öngören yedinci madddesinin işletilmesi gerektiğini öne sürerken, Rus yönetimi Çin ile birlikte bu öneriye karşı çıkmıştır. Bir kez daha uluslararası hukuk hükümlerine vurgu 
yapan Rusya Dışişleri Bakan Yardımcısı Sergey Riabkov, Suriye'nin OPCW'ye dahil olacağını söylediğini belirterek, söz konusu yedinci maddenin Suriye yönetiminin işbirliğini reddetmesi ya da bu konudaki yükümlülüklerini yerine getirmemesi halinde uygulanması gerektiğini savunmuştur (Zaman, 24 Eylül 2013).

Suriye krizinde büyük güçler arasındaki güçler dengesine, her ne kadar onlar kadar etkin olmasalar ve daha çok bu iki büyük gücün etrafında diğer dengeleyiciler olarak rol almış olsalar da $A B$ ve Çin'i de ekleyebiliriz. Örneğin $\mathrm{AB}$ ülkelerinin çoğunluğu, Suriye krizi ile ilgili olarak Esad rejimi karşısında yer alırken, kendileri tarafindan hazırlanan ve BM gündemine getirilen karar tasarılarının Rusya ve Çin'in vetoları nedeniyle reddedilmesini şiddetle eleştirmişlerdir. AB, aynı zamanda, kriz süresince Suriye'ye yönelik pek çok yaptırım uygulamıştır (Erdoğan, 2012). Çin ise Suriye krizi sırasında yoğun diplomasi girişimlerinde bulunmuş, gerek Esad'ın gerekse muhalif grupların görüşlerini almak için çaba sarfetmiş ve bölge ülkelerine özel elçi göndererek bu ülkelerin Suriye krizi konusundaki görüşlerini öğrenmeye çalışmıştır.

Çin, aynı zamanda, 4 Mart 2012 tarihinde Suriye'deki krizin çözümüne yönelik olarak altı maddelik bir teklifte bulunmuştur. BMGK'nın 21 Nisan 2012 tarihli kararı ile destek verdiği BM-Arap Birliği Suriye Özel temsilcisi Kofi Annan'ın planına ${ }^{4}$ büyük benzerlik gösteren bu teklif, uluslararası toplumun, "Suriye'nin bağımsızlı̆̆ göstermesi gerektiğini vurgulamakta ve sorunun siyaset ve diplomasi yöntemleri ile çözülmesi gerektiğine değinerek her türlü müdahaleye karş1 çıkmaktadır (Ekrem, 2012: 30-32). Şunu da belirtmek gerekir ki Çin bu teklife yine güçler dengesini gözeterek destek vermiştir. Çin'in kendi planını bırakıp Annan Planı'na destek vermesinin asıl nedeni ise, Rusya ile birlikte oluşturduğu güçler dengesi ayağının temel argümanı olan Suriye'de rejim değişikliği çağrısında bulunmaması ve kınama sözcüğünün BM Güvenlik Konseyi Başkanlığı'nın açıklamasında yer almamasıdır.

Güçler dengesi, yukarıda da sözü edildiği üzere, sadece büyük güçler arasında değil, aynı zamanda bölgesel güçler arasında da çalışan bir kurumdur.

\footnotetext{
${ }^{4}$ Mart 2012'de Arap Ligi ve BM'nin ortak girişimiyle ortaya konulan Annan Planı, Suriye'deki krizin çözümü yolunda siyasi bir süreç öngören altı maddelik bir plandır. Plan, özetle, rejimin Suriye halkının meşru taleplerine ve endişelerine yanıt vermesi, saldırıların sona erip ateşkesin sağlanması, insani yardımın sağlanması için gerekli önlemlerin alınması hatta belirli saatlerde çatışmaların durdurulması, keyfi olarak tutuklanan kişilerin serbest bırakılması, gazetecilerin ülke içinde serbestçe dolaşımının sağlanması ve örgütlenme ile barışçıl bir şekilde protesto etme özgürlügüune sayg1 duyulması gibi konuları içermekteydi (Al Jazeera, 27 March 2012).
} 
$\mathrm{Bu}$ nedenle $\mathrm{ABD}$, Rusya ve $\mathrm{AB}$ gibi büyük güçlerin yanı sıra Türkiye, İran ve Arap Birliği gibi bölgesel güçlerin Suriye politikası, yerel güçler dengesi ilkesinin işlerliğini ve yerel ve küresel güçler dengesinin zaman zaman çakışabileceğini göstermesi açısından önemlidir. Mart 2012'de Suriye'deki gelişmeleri görüşmek amacıyla Irak'ın başkenti Bağdat'ta toplanan Arap Birliği Zirvesi'nde Annan Planı'na destek çıkmıştır. Suriye'ye yapılacak herhangi bir müdahaleye karşı çıkılan ve Suriye'deki rejime diyalog çağrısında bulunulan Zirve'de, Suriye hükümetinden Annan'ın çözüm planının derhal ve eksiksiz şekilde uygulanması istenmiştir (Turan, 29 Mart 2012). Aynı tarihlerde Türkiye Dışişleri Bakanı Ahmet Davutoğlu da Annan Planı'nın Suriye rejimi için "son şans" olduğunu belirtmiştir (CBS News, 30 Mart 2012).

Suriye'nin en önemli bölgesel müttefiği olan İran da Annan Planı'nı desteklemiştir. ${ }^{5}$ Annan, Temmuz 2012'de Esad ile yaptığı görüşme sonucunda ülkede şiddeti sonlandıracak bir yaklaşımda anlaştıklarını belirttikten sonra, krizin çözümü hakkında görüşmelerde bulunmak amacıyla İran'a gitmiştir (Cumhuriyet, 9 Temmuz 2012). Bu görüşmenin ardından İran Dışişleri Bakanı Ali Ekber Salihi ile yaptıkları ortak basın toplantısında Annan, İran'ın Suriye'deki krizin çözümünde pozitif bir rol oynayabileceğini ve hatta çözümün mutlaka bir parçası olması gerektiğini belirtmiş, Salihi de bu konuda işbirliği yapacaklarını eklemiş̧ir (The Washington Post, 10 Temmuz 2014). Bu toplantıdan kısa bir süre sonra krizin çözümü ile ilgili Türkiye Dışişleri Bakanlığı Müsteşar Yardımcısı Halit Çevik ile Tahran'da görüşen Ali Ekber Salihi de Davutoğlu'nun açıklamasına benzer şekilde, tek çözüm yolunun Annan planının uygulanması olduğunu belirtmiştir (Milliyet, 01/08/2014).

Özetle bölge ülkeleri de krizin nasıl yönetileceği konusunda farklı kamplara ayrılmışlar ve çeşitli adımlarla birbirlerini dengeleme yoluna gitmişlerdir. Özellikle Türkiye'nin müdahaleci tutumu İran tarafından dengelenirken bölgesel güçler dengesi genel güçler dengesi kurumuna paralel olarak işlemiş ve tek taraflı hareketi önleyerek uluslararası toplumda düzenin korunmasına hizmet etmiştir. Güçler dengesi kurumu, büyük güçler yönetimi kurumuna da bir zemin oluşturmaktadır. Eğer Suriye krizinde bir güçler dengesi oluşmamış olsaydı, büyük güçler yönetimi kurumu çalışmayacaktı. Ancak güçler dengesi sayesinde ABD'nin müdahaleci tutumu Rusya tarafından dengelenmiş ve nihayetinde, büyük güçler yönetimi kurumu sayesinde iki tarafi da tatmin edecek olan Suriye'ye ait kimyasal silahların yok edilmesi üzerinde

5ं̇ran, özellikle bölgesel nüfuzunu azaltacağı gerekçesiyle Suriye’de Sünni bir yönetimin iktidara gelmesini istememekte ve askeri ve stratejik müttefiki Suriye'ye reformlar için zaman verilmesi gerektiğini savunmaktaydı (Ertuğrul, 2012: 1-5). 
anlaşılmıştır. Bu da ne ABD’nin müdahaleci tutumunun, ne de Rusya'nın Esad yanlısı görüşlerinin bire bir tezahürüdür. Dolayısıyla, küresel uluslararası toplum güçler dengesi kurumu vasıtasıyla da Suriye krizinde işlerliğini korumuştur.

\section{Suriye Krizinde Diplomasi}

Diplomasi kurumu ile ilgili olarak vurgulanması gereken ilk ve en önemli şey diplomasinin uluslararası toplumun iletişim aracı ve dili olduğudur. Başka bir deyişle, diplomasi, uluslararası toplumun alamet-i farikasıdır. Watson'ın (2005: 1-5) da belirttiği üzere, diplomasinin varlığı ve işlerliğinin sağlanması için devletlerin bir sistemden çok bir toplum biçiminde örgütlenmesi gerekmektedir. Bull (1985: 163-172), diplomasinin uluslararas1 toplumun varlığının sembolü olduğunu ve hem devletler hem de devlet dış1 aktörler arasında olabileceğini vurgulamaktadır. Suriye krizinde de hem Suriye devletini temsil eden Esad yönetimi hem de ona muhalefet eden çok parçaya bölünmüş güçler diplomatik sistemin içerisindedir.

Güçler dengesi kurumunda olduğu gibi, diplomasi de diğer kurumların işlemesinin sağlanmasında önemli rol oynayan bir kurumdur. Açıkça görülebileceği üzere diplomasi olmazsa ne büyük güçler yönetimi ne de uluslararası hukuk kurumu işleyemez. Bull'un da (1985: 170) vurguladığ 1 gibi "diplomasi hem siyasi liderler hem de diğer aktörler arasındaki iletişime olanak tanır." Doğal olarak bu iletişim koptuğunda, uluslararası toplumun bir nevi yön vericileri konumunda bulunan büyük güçler de birbirleri ile bağlantı kuramayacaklar ve uzlaşmaları mümkün olmayacaktır. Ancak Suriye krizinde görüyoruz ki aralarındaki fikir ayrılıklarına rağmen hem büyük güçler arasında hem de bölge ülkeleri ve Suriye'deki çatışan gruplar arasında daimi müzakere ve iletişim tahsis edilmiştir. Her ne kadar ABD ve diğer batılı güçler Suriye'ye müdahale yanlısı bir tutum sergileseler de Rusya ve Çin'in dahil olduğu grup, müdahalenin olumsuz yanlarına dikkat çekmeye çalışıp kriz süresince diplomasi çağrısı yapmıştır.

Suriye Halkının Dostları Grubu'nun düzenlediği konferanslar, Suriye krizinin çözümüne yönelik olarak gerçekleştirilen diplomatik girişimlerin en önemlilerindendir. Bu toplantıların ilki 24 Şubat 2012 tarihinde Tunus'ta düzenlenmiştir. Toplantıda $A B D$ ve Körfez ülkeleri gibi bazı ülkelerin temsilcileri askeri müdahalenin veya Suriye'deki muhalif grupları silahlandırmanın gerekliliğine vurgu yapmış olsalar da, konferansın sonuç bildirisinde bu konularla ilgili bir ifadeye rastlanmaması ilginçtir. Suriye'nin toprak bütünlügünün vurgulandığı ve Esad'a ülkedeki şiddeti durdurması için çağrıda bulunulan bildiride, Suriye'ye uygulanan diplomatik, siyasi ve iktisadi yaptırımların artırılması kararı alınmıştır (Reuters, 24 Şubat 2012). 
1 Nisan 2012'de İstanbul'da düzenlenen ikinci toplantıda Esad'ın Suriye halkının meşru taleplerine cevap vermesinin gerekliliğine vurgu yapılmış ve konferansın sonuçlarında, uluslararası toplum, Suriye'deki rejimin kendi halkına baskı yapmasını engellemek için rejime yönelik yaptırımların devamı ve artırılması gibi bütün tedbirleri almaya davet edilmiştir. 6 Temmuz 2012'de Paris'te düzenlenen üçüncü toplantıda ise, yine askeri müdahale çağrisı yapılmamış ve toplantı Suriye yönetimine yaptırım uygulanması çağrısıyla son bulmuştur. Toplantının sonuç bildirgesinde uluslararası toplumun Suriye'nin yeniden inşası esnasında halkın yanında olacağı mesajı verilmiştir (Al Jazeera Turk, 6 Termmuz 2012).

Diplomasi kurumunun işlerliğine bir başka örnek de 14 Eylül 2013 tarihli Cenevre Konferansidır. Bu konferansta Rusya ile ABD arasında Suriye'nin kimyasal silahları konusunda varılan mutabakatın ve bu iki ülkenin belirledikleri çerçevenin bir sonucu olarak Suriye'deki kimyasal silahların imhasıyla ilgili 2118 no'lu BM kararı alınmıştır. Konferans öncesinde Obama, bu kararın BMGK'dan geçmesi için Rusya ve Çin'le görüş alışverişinde olacaklarını belirtmiştir (BBC Türkçe, 11 Eylül 2013b). Cenevre 2 Zirvesi olarak bilinen Suriye Uluslararas1 Konferans1 öncesinde, Suriye'nin Dostları Çekirdek Grubu Türkiye'nin de bulunduğu 11 ülkenin katılımı ile 12 Ocak 2014'te Paris'te toplanmış, toplantıda İkinci Cenevre Zirvesi'nin gündem maddeleri ele alınmıştır. Suriye'deki geçiş döneminin ayrıntılarının belirleneceği Cenevre 2 Zirvesi ise 22 Ocak 2014'te Montrö'de başlamıştır. Muhalefet ve rejimin ayrı odalarda kalıp, mesajlarını Brahimi aracılığıyla birbirlerine ilettikleri zirvede farklı ülkelerden birçok diplomatın rejime ya da muhalefete diplomasi taktikleri vermesi, Cenevre görüşmelerinin "diplomasi oyunu" olarak adlandırılmasına neden olmuştur (Karabat, 24 Ocak 2014). Cenevre 2 Zirvesi sonrasında, Rusya ve Çin'in olumlu oy vermesi neticesinde BM Güvenlik Konseyi'nde, Suriye ile ilgili olarak kimyasal silahların imhası dışında bir kez daha oybirliği ile bir karar alınmıştır. Ülkede yaşanan insani krizin ve artan şiddetin son bulması gerektiğini vurgulayan 2139 no'lu bu karar, ülkeye yapılacak insani yardım ile ilgili olup, Suriye'deki rejime yönelik herhangi bir yaptırım kararı içermemektedir.

Diplomasi kurumu belki de en çok uluslararası hukuk kurumunun varllğğnı ve işlerliğini sağlar. Bilindiği üzere uluslararası toplum teorisinde uluslararası hukuk, devlet davranışı neticesinde doğar. Bu nedenle diplomasi olmazsa devletler arasında iletişim ve pratikte davranış olmayacağından bir uluslararası hukukun varlığından da söz edilemez. Dahası, Bull'un (1985: 170) belirttiği gibi diplomasinin bir işlevi de anlaşmaların müzakere edilmesidir ve uluslararası anlaşmalar uluslararası hukukun parçasıdırlar. Buradan hareketle eğer diplomasi olmazsa müzakere ve anlaşma da olmaz denilebilir. Suriye krizinde de diplomasi kurumu hem uluslararası hukukun işletilmesi hem de 
anlaşmaların müzakere edilmesinde çok önemli rol oynamıştır. Örneğin Suriye'nin elinde bulunan kimyasal silahların yok edilmesi anlaşması tamamen diplomasi kurumunun işlemesinin bir sonucudur.

Diplomasinin bir başka işlevi de yumuşatma rolüdür. Örneğin ABD, Rusya ve diğer bölge ülkeleri Suriye'de çatışan taraflar ile diplomatik temasları sonuna kadar sürdürerek savaş kurumunun çalışmasının önüne geçmişlerdir. Ancak Türkiye sadece Esad rejimine muhalif güçlerle temas kurarak ${ }^{6}$ bir diğer aktörün eyleminden haberdar olma ve ona göre konum alma firsatını kullanmamış, askeri anganjman kurallarını her iki ülke de birbirine karşı değiştirmiş ve diplomasinin bu yumuşatıcı etkisinden mahrum kalmışlardır. Çünkü uluslararası toplumda diplomasi anlaşmazlıkların etkisini minimuma indirme ve diğer ülkeler hakkında bilgi ve istihbarat toplama işlevini de görür (Bull, 1985: 171). Bu iki fonksiyon birlikte çalıştığında uluslararası toplumların üyeleri arasındaki ilişkileri yumuşatır. Başka bir deyişle diplomasi kurumu uluslararası toplumu mümkün kılan kurumdur ancak Türkiye ve Suriye artık uluslararası ilişkilerde toplumsal düzlemden ziyade sistemik düzeyde ilişkilerini sürdürmektedirler.

Sonuçta diplomasi kurumu Suriye krizinin ilk başladığı günden krizin en derinleştiği ve içinden çıkılmaz bir hal aldığı günlere kadar işlerliğini korumuş ve devletler arasında iletişimi sağlamıştır. Diplomasinin devamlılığı sayesinde uluslararası toplumun amaçlarına vurgu yapılmış ve devamlılı̆ 1 sağlanmış, devletler arasındaki şiddet sınılanmış, diğer kurumların işlerliği kolaylaştırılmıştır. $\mathrm{Bu}$ nedenlerle, diplomasi, uluslararası toplumun varlığını kanıtlayıcı en önemi kurumlardan biridir. Eğer günümüz uluslararası ilişkileri bir uluslararası toplumdan ziyade bir uluslararası sistem arz etse idi, aktörler arasındaki iletişim minimum düzeyde olacak ve "uluslararası hukuk" ya da "anlaşma" dediğimiz kavramlar bulunmayacaktı. Bunun yerine devletler daha mekanik davranışlarda bulunacak, örneğin güç politikası tamamen uluslararası ilişkilere hakim olacaktı.

\section{Suriye Krizinde Uluslararası Hukuk}

Uluslararası toplum teorisinde uluslararası hukuk pozitif hukuktur. Başka bir deyişle, uluslararası hukuk, devletler arasındaki pratikten kaynaklanmaktadır. Her ne kadar Wight (1991: 233) Grotius düşün geleneğinin

6Örneğin, bir dönem Suriye Kurtuluş Ordusu'nun merkez üssünün Hatay olduğu (Radikal, 29 Ağustos 2012), Türkiye'nin Suriyeli muhaliflerin liderleri ile yakın ilişki içerisinde olduğu ve savaşçılara lojistik destek sağladığ 1 sıklıkla basına yansımıştır (New York Times, 27 Ekim 2011). 
doğal hukuk ve uluslararası hukuk arasında bir orta yolu temsil ettiğini söylese de, bu gelenekte de büyük çapta değişimler olmuş ve uluslararası hukuk dediğimiz şey devlet pratiğine doğru bir eğilim göstermiştir. Wight (1991: 234), uluslararası hukukun, ortada hiç bir mahkeme kararı veya anlaşma olmadığında dahi gelenekler ve "medeni" ülkelerin onu kullanış biçimleri ile oluştuğunu yazmaktadır. $\mathrm{Bu}$ da devletler arası ilişkinin sınırlı olduğu durumlarda dahi uluslararası hukukun devlet pratiğine dayandığını göstermektedir.

C.A.W. Manning'e (1962: 113, 160-167) göre, uluslararası hukuk bağlayıcılı̆̆ını, bir topluma üye olmanın şartının bu hukuka göre eşit sayılmak olmasından almaktadır. Yani uluslararası topluma üye olabilmek için uluslararası hukuk kabul edilmelidir ve bir kere kabul edildiğinde bundan vazgeçilemez. Zira bu bağlılıktan ayrılmak aynı zamanda uluslararası toplumdan da ayrılmak demektir. Bull da uluslararası hukukun, modern uluslararası toplumunun ayırdedici prensiplerinin başında gelmekte olduğunu iddia etmektedir; çünkü uluslararası toplum ancak devletlerin "egemen" olduklarını karşılıklı tanımaları ile meydana gelir (Bull, 1985: 140). Bu nedenle uluslararası hukuk, modern uluslararası toplumun hem tanımlayıcı hem de kurucu prensibidir. Yani uluslararası hukuk en başta devletlerin varlığını mümkün kılar. Suriye krizinde de özellikle Rusya, uluslararası hukukun bu prensibine vurgu yapmış ve bu kurumun uluslararası toplum adına sonuna kadar işletilmesi gerektiğini savunmuştur. Örneğin Putin, daha önce bahsi geçen makalesinde, Rusya'nın iddia edildiği gibi Suriye halkını değil uluslararası hukuku koruduğunu belirterek, "Beğensek de beğenmesek de hukuku uygulamak zorundayız. Mevcut uluslararası hukukta güce ancak meşru müdafaa veya Güvenlik Konseyi kararı çerçevesinde izin verilir" diyerek Rusya'nın askeri müdahalenin uygulanmasına karşı olduğunu tekrar vurgulamıştır.

Putin ayrıca, uluslararası toplumun tüm üyelerinin Suriye hükümetinin kimyasal silah depolarını uluslararası kontrole açmayı ve aşamalı olarak imhayı kabul etmiş olmasından faydalanması gerektiğini belirtmiştir. Ancak 5-6 Eylül 2013 tarihlerinde Rusya'da toplanan G-20 zirvesinin öncesinde ABD Senatosu Dış İlişkiler Komitesi Suriye'deki rejimin kimyasal silah kullandığı iddiaları nedeniyle iki ay içinde Suriye'ye müdahale etmeyi içeren önergeyi kabul etmiş; bunun üzerine Putin, BM kararı olmaksızın Suriye'ye yapılacak bir müdahalenin "saldırganlık" olacağını zira bu konuda kanıtların öncelikli olarak BMGK gündemine getirilmesi gerektiğini belirtmiştir. Obama ise uluslararası toplumun "inandırıcılığının" risk altında olduğunu iddia etmiştir. Ancak 7 Eylül 2013 tarihli bir haberde de (Zaman) belirtildiği üzere, Putin ve Obama arasındaki görüşmede iki ülkenin dışişleri bakanlarının Suriye'ye ilişkin siyasi 
çözüm konusundaki alternatifler üzerinde kısa sürede görüşeceği konusunda mutabık kalınmıştır.

Bull (1985: 141) uluslararası hukukun düzene katk1 yapma noktasında bir diğer rolünü "ulus devletlerin bir arada yaşamasının temel prensiplerini ortaya koyma" olarak tanımlamaktadır. Bu prensipler ise şiddetin sınırlanması, ahde vefa ve müdahale etmemedir. Suriye krizinde de yukarıda ayrıntılı olarak değinildiği üzere müdahale etmeme prensibine son noktaya kadar uyulmuş, ancak kimyasal silah kullanımı gündeme geldiğinde müdahale seçeneği masaya konmuştur. $\mathrm{Bu}$ durum hem şiddetin sinırlanması hem de ahde vefa prensiplerinin açık birer örneğidir. Suriye kriz öncesinde her ne kadar 1997 tarihli Kimyasal Silahların Geliştirilmesinin, Üretiminin, Stoklanmasının ve Kullanımının Yasaklanması ve Bunların İmhası Hakkındaki Sözleşme’ye taraf olmasa $\mathrm{da}^{7} 2118$ numaralı BMGK kararına uymuş ve elindeki kimyasal silahların OPCW gözetiminde imha edilmesini kabul etmiştir (BBC Türkçe, 18 Eylül 2013 ve 19 Eylül 2013; İHA, 30 Eylül 2013 ve Al Jazeera Türk, 14 Kasim 2013).

Uluslararası toplum kimyasal silahların yok edilmesinden ve Suriye'ye müdahale edilmemesinden hareketle, şiddeti bir noktaya kadar sınırlamış kabul edilebilir. Çakmak'ın da (2012: 57) belirttiği üzere, İkinci Dünya Savaşı sonrasında kurulan yeni düzende devletlerin iç işlerine karışmama, egemenlik ve sınırların korunması ilkeleri uluslararası hukuk ile güvenceye alınmış, bu durumların istisnası ise ancak uluslararası güvenlik ve istikrarın tehlikeye girmesi olmuştur. Bu durumlarda bile kuvvet kullanma yetkisi devletlere değil, BMGK'ya verilmiştir. Bilindiği gibi ABD kriz süresince Suriye'de rejimi sivil halka karşı kimyasal silah kullanmakla suçlamış ve bu iddialar nedeniyle Suriye'ye müdahale yapılıp yapılmaması konusu ABD Kongresi'nde sıklıkla tartışılmıştır. Fakat daha önce de değinildiği üzere ABD uzun süre müdahaleye karş1 mesafeli durmuştur. 21 Ağustos 2013'te meydana gelen kimyasal saldırıyla ilgili iddiaların yoğunlaşmasının ardından ise ABD kimyasal silahlar konusundaki tavrını kesinleştirmiş ve Suriye'ye müdahale hazırlıklarına başladığını duyurmuştur. Ancak 10 Eylül 2013'e kadar askeri müdahale ile ilgili Kongre'nin desteğini almaya çalışan Obama, Suriye rejiminin kimyasal silahlara sahip olduğunu itiraf etmesinin ve Rusya'nın Suriye'nin kimyasal silah stoklarını güven altına almak için hazırladığı planı ABD'ye sunmasının ardından Rusya'nın planına destek çıkacağını söylemiştir (BBC Türkçe, 5 Eylül 2013; 11 Eylül 2013a ve 11 Eylül 2013b). Bu sürecin bir sonucu olarak

\footnotetext{
${ }^{7}$ Suriye bu sözleşmeye 14 Eylül 2013 tarihinde üye olmuştur ve Suriye'deki kimyasal silahların imhası bu üyeliğe dayanmaktadır. OPCW üye ülkeler listesi için bkz: http://www.opcw.org/about-opcw/member-states/member-states-by-region
} 
Obama, 2118 no'lu BM kararının alınmasını sağlayan Birinci Cenevre Konferans1 öncesinde yaptığ 1 ulusa sesleniş konuşmasında Kongre'den Suriye'ye askeri müdahale oylamasını ertelemelerini istediğini belirtmiştir. Obama'nın belirttiği üzere, müdahalenin amaçlarından biri uluslararası toplumun kimyasal silah kullanımını hoşgörmeyeceğini göstermektir. Suriye'de güç kullanmanın ülkedeki iç savaşa bir çözüm getirmeyeceğine inandığı için müdahale çağrılarına uzun süre direndiğini belirten Obama, sadece diplomatik girişimlerin başarısız olması durumunda güç kullanma tehdidine başvuracağını söylemiştir (BBC Türkçe, 11 Eylül 2013b).

Suriye krizi özellikle kimyasal silahların imhası süreciyle ve Suriye'nin toprak bütünlüğünün korunarak, müdahale edilmemesi ile uluslararası hukuk kurumunun işleyişine örnek oluşturmaktadır. Öncelikle Suriye egemen bir devlet olarak uluslararası toplumun bir üyesi kabul edilmiş ve kriz süresince uluslararası hukukun egemenliğe sayg1 ve müdahale etmeme ilkeleri işletilmiştir. Daha sonra, her iki büyük güç de uluslararası hukukun davranışlarında yol gösterici olduğu ve bu kurumun uluslararası toplumun zemini olduğu vurgusunu defalarca yapmışlardır. Neticesinde bu zemin kimyasal silahların imha edilmesi konusunda somutlaşmış ve kriz tamamiyle uluslararası hukuk pratiği ile yönetilmiştir. Bunun neticesinde anlaşmaya ve ahde vefa ilkesine uygun olarak Suriye ilk önce OPCW gözlemcilerini ülkeye davet etmiş (OPCW, 13 Eylül 2013), daha sonra kimyasal silahların imhasına başlanmış (OPCW, 6 Ekim 2013) ve nihayetinde tüm kimyasal silahlar Suriye'den çıkarılmıştır (OPCW, 24 Temmuz 2014).

\section{Sonuç}

Bu çalışmada uluslararası toplumun sadece bir kavram ve kuramsal yaklaşım olmadığı, aksine uluslararası ilişkilerin gerçekliğini oluşturduğu öne sürülmüştür. Uluslararası toplumun varlığının ve işlerliğinin büyük güçler yönetimi, diplomasi, güçler dengesi ve uluslararası hukuk gibi kurumlarının çalışması vasıtasıyla kanıtlanabileceği iddiası çerçevesinde, Suriye krizi örnek olay olarak ele alınmış ve uluslararası toplumun bu krize nasıl yanıt verdiği incelenmiştir. Suriye krizinde kurumlar, uluslararası toplumun varlığının devamı, uluslararası toplumun üyelerinin bekalarının korunması, göreli barışın sağlanması ve şiddetin sınırlanması gibi amaçlar doğrultusunda gerek tek tek gerekse hep birlikte işleyerek uluslararası toplumun gerçekliğini meydana getirmişlerdir. Örneğin, kriz süresince $A B D$ ve $A B$ gibi büyük güçlerin müdahale yanlısı tutumları, Rusya ve Çin'in muhalefeti ile dengelenmiş, bölgesel ve küresel güçler arasındaki görüş farklılıkları sonucunda güçler dengesi kurumu işlemiştir. Güçler dengesi kurumu, aynı zamanda, gerek ABD gerekse Rusya'nın tek taraflı hareket etmesini önlemiştir. Yine bu kurumun bir 
neticesi olarak Moskova ve Çin, sürekli olarak uluslararası hukuka ve diplomasinin gerekliliğine vurgu yapmış ve müdahalenin olumsuz yanlarına dikkat çekmeye çalışmıştır. Bu iki ülkenin diplomasi çağrısı, kriz süresince uluslararası hukuk kurumunun da işlerliğini sağlamıştır.

Suriye krizi uluslararası toplumda düzen ile üç noktada kesişmektedir. Bunlardan birincisi krizin, göreli barışın sağlanması ve şiddetin sınırlanması amaçlarına oluşturduğu tehdittir. $\mathrm{Bu}$ tehdit özellikle büyük güç yönetimi ve uluslararası hukuk kurumlarının işletilmesi vasıtası ile sınırlanmıştır. Her ne kadar Suriye'de süregiden bir iç savaş olsa dahi bu iç savaşın devletler arası bir çatışmaya dönüşmesi, müdahalenin kimyasal silahların imhası ile sınırlandırılması yoluyla önlenmiştir. İkinci olarak Suriye'deki durum, uluslararası toplumun varlığının bir diğer amacı olan üyelerin bekalarını sağlama prensibine de ters düşmektedir. Suriye'ye olası bir askeri müdahalenin kurumların çalışması vasıtası ile önüne geçilmiş olması devletin varlığının devamını sağlamıştır. Suriye ve Beşar Esad yönetiminin varlığını sürdürmesi diplomasi ve güçler dengesi kurumlarının çalışması sayesindedir. Üçüncü ve son olarak, çoğulculuk ile dayanışmacılık arasındaki ikilem Suriye krizi nedeniyle tekrar uluslararası toplumun gündemine gelmiş ve uluslararası toplum müdahale etmemeyi seçerek çoğulcu niteliğini devam ettirmiştir.

\section{Kaynakça}

Akgün, Birol (2012), "ABD'nin Suriye Politikası", Akgün, Birol (Der.), Suriye Krizi'nde Bölgesel ve Küresel Aktörler: Perspektifler, Sorunlar ve Çözüm Önerileri (Ankara: Stratejik Düşünce Enstitüsü): 10-15.

Al Jazeera (27 Mart 2012), "Kofi Annan's six-point plan for Syria". http://www.aljazeera.com/news/middleeast/2012/03/2012327153111767387.html/ (17.06.2014).

Al Jazeera Turk (14 Kasım 2013), "Putin'den Esed'e 'destek' telefonu", http://www.aljazeera.com.tr/haber/putinden-esede-destek-telefonu (31.07.2014).

Al Jazeera Turk (19 Temmuz 2012), "Rusya'yla Çin'den üçüncü veto", http://staff.aljazeera.com.tr/haber/rusyayla-cinden-ucuncu-veto (16.06.2014).

Al Jazeera Turk (6 Termmuz 2012), "Suriye'ye Yaptırım Uygulansın", http://mon-wwwa1.aljazeera.com.tr/haber/suriyeye-yaptirim-uygulansin (11.06.2014).

Anadolu Ajansı (22 Mayıs 2014), "Rusya ve Çin'den veto”, http://www.aa.com.tr/tr/haberler/332955-rusya-ve-cinden-veto (16.06.2014).

BBC Türkçe (11 Eylül 2013a), "Suriye krizi: Rusya kimyasal silah planını ABD'ye iletti", http://www.bbc.co.uk/turkce/haberler/2013/09/130911_rusya_kimyasal_onerisi.shtml (13.06.2014). 
BBC Türkçe (11 Eylül 2013b), Suriye: "Obama kongreden oylamayı ertelemesini istedi", http://www.bbc.co.uk/turkce/haberler/2013/09/130910_obama_ulusa_seslenis.shtml (08.06.2014).

BBC Türkçe (12 Eylül 2013), "Suriye: Cenevre öncesi Putin'den ABD’ye 'diplomasi çağrısı", http://www.bbc.co.uk/turkce/haberler/2013/09/130911_cenevre_suriye.shtml (08.06.2014).

BBC Türkçe (18 Eylül 2013), “Suriye'den Rusya'ya 'kanıt': Saldırı muhaliflerin işi”, http://www.bbc.co.uk/turkce/haberler/2013/09/130918_suriye_rusya_bm.shtm (31.07.2014).

BBC Türkçe (19 Eylül 2013), "Esad: Silahları yok etmek bir yıl sürer", http://www.bbc.co.uk/turkce/haberler/2013/09/130919_esad_kimyasal.shtml (31.07.2014).

BBC Türkçe (30 Mart 2012), "Annan: Suriye ateşkesi derhal uygulamalı", http://www.bbc.co.uk/turkce/haberler/2012/03/120330_syria_annan.shtml (24/07/2014).

BBC Türkçe (5 Ekim 2011), “Suriye'ye BM baskısını artırma girişimi veto edildi”, http://www.bbc.co.uk/turkce/haberler/2011/10/111005_syria_un.shtml (16.06.2014).

BBC Türkçe (5 Eylül 2013), “G20: Suriye'ye Askeri Müdahale Tartışılıyor”, http://www.bbc.co.uk/turkce/haberler/2013/09/130905_g20_suriye_rusya.shtml (13.06.2013).

Black, Ian (2013), "Will chemical weapons in Syria be the 'red line' Barack Obama promised?", http://www.theguardian.com/world/2013/apr/23/chemical-weapons-red-line-obama (17.06.2014).

Buçukcu, Öner (2011), "Genel Bilgiler", Akgün, Birol (Der.), Suriye Krizi’nde Bölgesel ve Küresel Aktörler: Perspektifler, Sorunlar ve Çözüm Önerileri (Ankara: Stratejik Düşünce Enstitüsü): 4-9.

Bull, Hedley (1966), "The Grotian Conception of International Society”, Herbert Butterfield ve Martin Wight (Der.), Diplomatic Investigations (London: George Allen \& Unwin): 51-73.

Bull, Hedley (1976), "Martin Wight and the Theory of International Relations", British Journal of International Politics 2: 101-116.

Bull, Hedley (1979), “The State's Positive Role in World Affairs”, Daedalus, 108 (4): 111-123.

Bull, Hedley (1980), "The Great Irresponsibles? The United States, the Soviet Union, and World Order", International Journal, 35 (3): 437-447.

Bull, Hedley (1985), The Anarchical Society: A Study of Order in World Politics (Hong Kong: Macmillan).

Bull, Hedley ve Adam Watson (1984), "Introduction”, Hedley Bull ve Adam Watson (Der.), The Expansion of International Society (Oxford: Clarendon Press).

Bull, Hedley, (1977), "Martin Wight and the Study of International Relations", Martin Wight, Hedley Bull (Der.), Systems of States (Leicester: Leicester University Press).

Butterfield, Herbert (1966), "The Balance of Power" Herbert Butterfield ve Martin Wight (Der.), Diplomatic Investigations (London: George Allen \& Unwin): 132-148.

Buzan, Barry (2001), "The English School: an Underexploited Resource in IR", Review of International Studies, 27 (3): 471-488.

Buzan, Barry (2004), From International Society to World Society?: English School Theory and the Social Structure of the Globalisation, (Cambridge: Cambridge University Press).

Buzan, Barry (2010), "Culture and International Society", International Affairs, 86 (1): 1-25. 
Çakmak, Cenap (2012), "Suriye'de Kriz ve Uluslararası Hukuk", Akgün, Birol (Der.), Suriye Krizi'nde Bölgesel ve Küresel Aktörler: Perspektifler, Sorunlar ve Çözüm Önerileri (Ankara: Stratejik Düşünce Enstitüsü): 53-58.

CBS News (30 Mart 2012), "Turkey: Annan plan is last chance for Syria", http://www.cbsnews.com/news/turkey-annan-plan-is-last-chance-for-syria/ (24.07.2014).

Clark, Ian (2003), "Legitimacy in a Global Order”, Review of International Studies, 29 (S1): 75-95.

Clark, Ian (2007), Legitimacy in International Society, (Oxford: Oxford University Press).

Clark, Ian (2009), "Towards an English School Theory of Hegemony, European Journal of International Relations, 15 (2): 203-228.

Clark, lan (2011), Hegemony in International Society, (Oxford: Oxford University Press).

Cumhuriyet (09 Temmuz 2012), “Annan, Esad ile görüştü, İran'a gitti”, http://www.cumhuriyet.com.tr/haber/diger/355766/Annan_Esad_ile_gorustu_iran_a_git ti.html (24/07/2014).

Cumhuriyet (31 Temmuz 2014), “Obama ve Putin Uktayna'yı görüştü”, http://www.cumhuriyet.com.tr/haber/turkiye/86413/Obama ve Putin_Ukrayna yi gorustu .html (31.07.2014)

Dısişleri Bakanlığı (1 Nisan 2012) "Suriye Halkının Dostları Grubu İkinci Konferansı Başkanlık Sonuçları", http://www.mfa.gov.tr/chairman_s-conclusions-second-conference-of---thegroup-of-friends-of-the-syrian-people-istanbul_-1-april-2012.tr.mfa (11.06.2014).

Doster, Barış (2012), "Batının Suriye Açmazı”, Ortadoğu Analiz, 4 (47): 30-38.

Ekrem, Erkin (2012), “Çin'in Suriye Politikası ve Çözüm Planı”, Akgün, Birol (Der.), Suriye Krizi'nde Bölgesel ve Küresel Aktörler: Perspektifler, Sorunlar ve Çözüm Önerileri (Ankara: Stratejik Düşünce Enstitüsü): 28-35.

Erdoğan, Murat. (2012), "Avrupa Birliği'nin Suriye Politikası” Akgün, Birol (Der.), Suriye Krizi'nde Bölgesel ve Küresel Aktörler: Perspektifler, Sorunlar ve Çözüm Önerileri (Ankara: Stratejik Düşünce Enstitüsü): 16-21.

Ertuğrul, Doğan (2012). "Türkiye Dış Politikası için bir Test: Suriye Krizi”, TESEV Dış Politika Programı.

Gong, Gerrit (1984), The Standard of Civilization in International Society, (Oxford: Clarendon).

Griffiths, Martin ve Terry O'Callaghan (2002), International Relations: Key Concepts, (London: Routledge).

Haaretz (8 Haziran 2014), "Syria turning into a warlord-run failed state, says former peace envoy", http://www.haaretz.com/news/middle-east/1.597626 (09.06.2014).

Hürriyet (10 Eylül 2013), "Suriye Rusya'nın kimyasal silahlarla ilgili teklifini kabul etti", http://www.hurriyet.com.tr/planet/24681397.asp (30.11.2014).

Hürriyet (15 Eylül 2013), "ABD ile Rusya Suriye Konusunda Anlaştı", http://www.hurriyet.com.tr/planet/24709740.asp (30.11.2014).

İHA (30 Eyül 2013), "Beşar Esad, 'Kimyasal silah anlaşmasına uyacağız", http://www.iha.com.tr/haber-besar-esad-e28098kimyasal-silah-anlasmasina-uyacagizdunya-302538/ (31.07.2014).

Jackson, Robert (2003), The Global Covenant: Human Conduct in a World of States, (New York: Oxford University Press).

James, Alan (1978), "International Society", British Journal of International Studies, 4: 91-106. 
Kalaycı, Sezai (28 Eylül 2013), "Suriye karar tasarısı BM Güvenlik Konseyi'nde kabul edildi", http://www.zaman.com.tr/dunya_suriye-karar-tasarisi-bm-guvenlik-konseyinde-kabuledildi_2143491.html (05.06.2014).

Karabat, Ayşe (24 Ocak 2014), "Suriye için diplomasi oyunu başladı", http://www.aljazeera.com.tr/haber-analiz/suriye-icin-diplomasi-oyunu-basladi (07.06.2014).

Kaya, İbrahim (2012), "Suriye'de 'iç Savaş' ve Uluslararası Hukuk", USAK Stratejik Gündem, http://www.usakgundem.com/yazar/2487/suriye\%E2\%80\%99de\%E2\%80\%98\%C4\%B0\%C3\%A7-sava\%C5\%9F\%E2\%80\%99-ve-uluslararas\%C4\%B1hukuk.html (05.06.2014).

Köroğlu, Uğur (2012), “İran'ın Suriye Politikası”, Akgün, Birol (Der.), Suriye Krizi’nde Bölgesel ve Küresel Aktörler: Perspektifler, Sorunlar ve Çözüm Önerileri (Ankara: Stratejik Düşünce Enstitüsü): 44-52.

Küçükkeleş, Müjge. (2012), “Arap Birliği'nin Suriye Politikası”, Seta Analiz. 51: 1-21.

Manning, Charles, A. W. (1962), The Nature of International Society, (Great Britain: Wiley).

Mayall, James (2002), World Politics: Progress and Limits, (Cambridge: Polity).

Mearshiemer, John (1994), "The False Promise of International Institutions", International Security, 19 (3): 5-49.

Milliyet (01/08/2012), "İran: "Tek çözüm Annan planı", http://www.milliyet.com.tr/iran-tek-cozumannan-plani-/dunya/dunyadetay/01.08.2012/1574739/default.htm (24.07.2014).

Northedge, Frederick (1981), The International Political System, (London: Faber Paperbacks).

Ntvmsnbc (4 Şubat 2012), "Suriye tasarısına Rusya ve Çin'den veto", http://www.ntvmsnbc.com/id/25319438/ (16.06.2014).

OPCW (13 Eylül 2013), "OPCW to Review Request from Syria", http://www.opcw.org/news/article/opcw-to-review-request-from-syria/ (31.07.2014).

OPCW (24 Temmuz 2014), "OPCW Maritime Operation Completes Deliveries of Syrian Chemicals to Commercial Destruction Facilities", http://www.opcw.org/news/article/opcw-maritimeoperation-completes-deliveries-of-syrian-chemicals-to-commercial-destruction-facilitie/ (31.07.2014)

OPCW (6 Ekim 2013), "Syria Chemical Weapons Destruction Begins", http://www.opcw.org/news/article/syria-chemical-weapons-destruction-begins/ (31.07.2014)

Putin, Vladimir (11 September 2013), "A Plea for Caution from Russia", http://www.nytimes.com/2013/09/12/opinion/putin-plea-for-caution-from-russia-onsyria.html?_r=0 (03.06.2014).

Radikal (19 Temmuz 2012), "Rusya ve Çin'den Suriye yaptırımlarına veto", http://www.radikal.com.tr/dunya/rusya ve cinden_suriye_yaptirimlarina veto-1094659 (16.06. 2014)

Radikal (29 Ağustos 2012), “Özgür Suriye Ordusu'nın merkez üssü Hatay'mış”, http://www.radikal.com.tr/turkiye/ozgur_suriye_ordusunun_merkez ussu hataymis1098574 (31.07.2014).

Ranke, Leopold von (1981), The Secret of World History: Selected Writings on the Art and Science of History, Roger Wines (Der.), (New York: Fordham University Press).

Report of the United Nations Mission to Investigate Allegations of the Use of Chemical Weapons in the Syrian Arab Republic on the alleged use of chemical weapons in the Ghouta area of 
Damascus on 21 August 2013.(16 September 2013). United Nations General Assembly Sixty-Seventh Session. A/67/997-S/2013/553 http://www.securitycouncilreport.org/att/cf/\%7B65BFCF9B-6D27-4E9C-8CD3CF6E4FF96FF9\%7D/s_2013_553.pdf (05.06.2014).

Reuters (24 Şubat 2014), "Friends of Syria' condemn Assad but see more killing", http://www.reuters.com/article/2012/02/24/us-syria-meeting-tunisidUSTRE81N16820120224 (11.06.2014).

Slater, Jerome ve Terry Nardin (1986), "Nonintervention and Human Rights", The Journal of Politics, 48 (1): 86-96.

Stack, Liam (2011), "In Slap at Syria, Turkey Shelters Anti-Assad Fighters", http://www.nytimes.com/2011/10/28/world/europe/turkey-is-sheltering-antigovernmentsyrian-militia.html?pagewanted=all\&_r=1\& (31.07.2014).

Syrian Observatory for Human Rights (19 Mayıs 2014), "More than 162,000 dead in Syria's since 18/03/2011",

http://syriahr.com/en/index.php?option=com_news\&nid=2275\&ltemid=2\&task=displayne ws\#.U6AoqZR_uz4 (17.06.2014).

Tanrısever, Oktay (2007), "Güç", Devlet ve Ötesi: Uluslararası İlişkilerde Temel Kavramlar, Atila Eralp (Der.), (İstanbul: İletişim Yayınları): 53-71

Turan, Metin (29 Mart 2012), “Arap Birliği Zirvesi'nden Annan'a Destek Çıktı”, http://www.radikal.com.tr/dunya/arap_birligi_zirvesinden_annana_destek_cikti-1083320 (24.07.2014).

United Nations Security Council Resolution 2043 (21 Nisan 2012) S/RES/2043 (2012). http://www.securitycouncilreport.org/att/cf/\%7B65BFCF9B-6D27-4E9C-8CD3CF6E4FF96FF9\%7D/Syria\% 20SRES\%202043.pdf (10.07.2014).

United Nations Security Council Resolution 2118 (27 Eylül 2013), S/RES/2118, http://www.un.org/en/ga/ search/view_doc.asp?symbol=S/RES/2118(2013) (05.06.2014).

United Nations Security Council Resolution 2139 (22 Şubat 2014), S/RES/2139, http://www.un.org/en/ga/search/view_doc.asp?symbol=S/RES/2139(2014) (31.07.2014).

United Nations Supervision Mission in Syria, http:/www.un.org/en/peacekeeping/missions/unsmis/ (05.06.2014).

Uysal, Ahmet (2012), "Suriye Krizi ve İslam Dünyası", Akgün, Birol (Der.), Suriye Krizi'nde Bölgesel ve Küresel Aktörler: Perspektifler, Sorunlar ve Çözüm Önerileri (Ankara: Stratejik Düşünce Enstitüsü): 36-39.

Vincent, Raymond J. (1995), Human Rights and International Relations (Cambridge: Cambridge University Press).

Walt, Stephan (1998), "One World, Many Theories", Foreign Policy, 110: $29-46$.

Waltz, Kenneth (1959), Man the State and War: A Theoretical Analysis (New York: Colombia University Press).

Waltz, Kenneth (1979), Theory of International Politics (USA: Addison-Wesley Publishing Company).

Washington Post (10 Temmuz 2014), "Kofi Annan says Iran can help end Syria crisis", http://www.washingtonpost.com/world/kofi-annan-says-iran-can-help-end-syriacrisis/2012/07/10/gJQA dNpUaW_story.html (24.07.2014).

Watson, Adam (1987), "Hedley Bull, States Systems and International Societies", Review of International Studies, 13 (2): 147-153. 
Watson, Adam (1990), "Systems of States", Review of International Studies, 16 (2): 99-109.

Watson, Adam (2002), The Evolution of International Society, (London: Routledge).

Watson, Adam (2005), Diplomacy: The Dialogue Between States, (Taylor \& Francis e-Publishing).

Wheeler, Nicholas (1992), "Pluralist or Solidarist Conceptions of International Society: Bull and Vincent on Humanitarian Intervention", Millennium - Journal of International Studies, 21 (3): 463-487.

White House (6 Mart 2012), "Press Conference by the President", http://www.whitehouse.gov/thepress-office/2012/03/06/press-conference-president(17.06.2014).

Wight, Martin (1966), "The Balance of Power" Herbert Butterfield ve Martin Wight (Der.), Diplomatic Investigations (London: George Allen \& Unwin): 149-175.

Wight, Martin (1977), Systems of States, Hedley Bull (Der.), (Leicester: Leicester University Press).

Wight, Martin (1978), Power Politics (Leicester: Leicester University Press).

Wight, Martin (1991), International Theory: The Three Traditions, (Great Britain: Leicester University Press).

Yazıcı, Amine (2012), “Rusya'nın Suriye Politikası”, Akgün, Birol (Der.), Suriye Krizi'nde Bölgesel ve Küresel Aktörler: Perspektifler, Sorunlar ve Çözüm Önerileri (Ankara: Stratejik Düşünce Enstitüsü): 40-43.

Yurdusev, A. Nuri (2005), “Uluslararası İlişkilere Teorik Bakmak”, Uluslararası Iliş̧kiler, 2 (6): 157163.

Zaman (24 Eylül 2013), "Rusya, Suriye'ye Otomatik Yaptırım ve Askeri Müdahaleye Karşı", http://www.zaman.com.tr/dunya_rusya-suriyeye-otomatik-yaptirim-ve-askerimudahaleye-karsi_2141100.html (23/07/2014).

Zaman (7 Eylül 2013), "Kerry, Lavrov'un telefonuna cevap verdi, 40 dakika Suriye konuştular", http://www.zaman.com.tr/dunya_kerry-lavrovun-telefonuna-cevap-verdi-40-dakika-suriyekonustular_2131503.html (16.03.2014). 